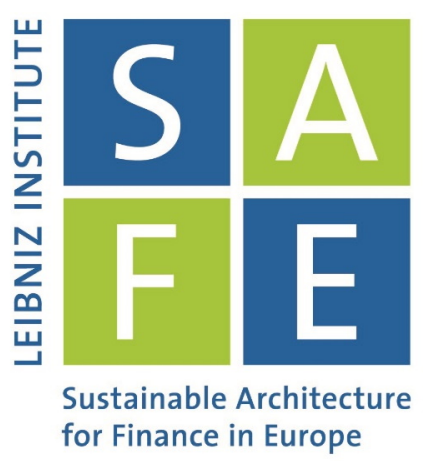

Reint Gropp | Thomas Mosk | Steven Ongena | Ines Simac | Carlo Wix

\title{
Supranational Rules, National Discretion: Increasing Versus Inflating Regulatory Bank Capital?
}

SAFE Working Paper No. 296

\section{Leibniz Institute for Financial Research SAFE}

Sustainable Architecture for Finance in Europe 


\title{
Supranational Rules, National Discretion: Increasing versus Inflating Regulatory Bank Capital?
}

\author{
Reint Gropp ${ }^{1} \quad$ Thomas Mosk ${ }^{2} \quad$ Steven Ongena $^{3} \quad$ Ines Simac $^{4} \quad$ Carlo Wix $^{5}$
}

This version: November 15, 2020

\begin{abstract}
We study how higher capital requirements introduced at the supranational level affect the regulatory capital of banks across countries. Using the 2011 EBA capital exercise as a quasi-natural experiment, we find that treated banks exploit discretion in the calculation of regulatory capital to inflate their capital ratios without a commensurate increase in their book equity and without a reduction in bank risk. Regulatory capital inflation is more pronounced in countries where credit supply is expected to tighten, suggesting that national authorities forbear their domestic banks to meet supranational requirements, with a focus on short-term economic considerations.
\end{abstract}

\footnotetext{
${ }^{1}$ Halle Institute for Economic Research, University of Magdeburg, and CEPR

${ }^{2}$ University of Zurich and Research Center SAFE

${ }^{3}$ University of Zurich, Swiss Finance Institute, KU Leuven, and CEPR

${ }^{4} \mathrm{KU}$ Leuven

${ }^{5}$ Federal Reserve Board

For helpful comments and suggestions, we would like to thank Tobias Berg, Missaka Warusawitharana, and the conference and seminar participants at the SFI-Capco Institute Banking \& Finance Forum 2019, the European Banking Authority (EBA), and the Federal Reserve Board. The views expressed in this paper solely reflect those of the authors and not necessarily those of the Federal Reserve Board, the Federal Reserve System as a whole, nor of anyone associated with the Federal Reserve System. Ongena acknowledges financial support from ERC ADG 2016 GA 740272 lending.
} 
The regulatory framework introduced after the 2008/2009 financial crisis required banks to increase their regulatory capital ratios to foster financial stability. Capital ratios as a policy tool, however, are frequently criticized for being too complex, too opaque, and for their calculation being subject to too much supervisory discretion (Haldane, 2012, 2013). While much of this debate has centered on the calculation of risk-weighted assets in the denominator of the capital ratio (Acharya, Engle, and Pierret, 2014; Behn, Haselmann, and Vig, 2016; Plosser and Santos, 2018), the calculation of the numerator, regulatory capital, has received much less attention so far. However, the calculation of regulatory capital (which differs from book equity) is complex as well and provides banks with considerable leeway to inflate their capital ratios. Furthermore, for this purpose, regulatory capital inflation can achieve more "bang for the buck" than a reduction in risk-weighted assets. $^{1}$

Our study addresses this gap in the literature by examining how banks respond to a sudden supranational increase in capital requirements. We document how banks rely on discretion in the calculation of regulatory capital to inflate their capital ratios without a commensurate increase in their levels of book equity. This discretion - it turns out - is provided to them by their own national regulatory authorities. The rules governing the definition of regulatory capital include a plethora of deductions and instruments that vary across countries. Such national discretion in the implementation of supranational rules (Angeloni, 2014) allows banks and national authorities to inflate banks' regulatory capital ratios.

To calculate regulatory capital, banks must deduct several items from their book equity that are not considered to increase a bank's capability to absorb losses (BCBS, 2015). For many banks, these capital deductions are large in magnitude and drive a sizable wedge between their book equity and their regulatory capital. If banks can discretionarily reduce these deductions, then such adjustments will allow banks to increase their levels of regulatory capital without issuing (costly) equity or retaining additional earnings. ${ }^{2}$ National authorities may assist banks' efforts to inflate their regulatory capital by exercising regulatory forbearance, such as by enacting favorable regulations or by making certain capital instruments eligible for regulatory capital. Therefore, while

\footnotetext{
${ }^{1}$ For a bank with e.g. a 9 percent regulatory capital ratio, a marginal one dollar increase in regulatory capital increases the capital ratio as much as a marginal ten dollar reduction in risk-weighted assets.

${ }^{2}$ While having received little attention in the literature, such capital measures are prevalent in practice. Financial consultancies advice banks to "improve regulatory capital [...] by reducing capital deductions (such as minority interests, goodwill, intangibles, and nonconsolidated investments)" (McKinsey, 2017).
} 
supranational rules should be binding in theory, national discretion may effectively undermine them in practice.

Identifying such regulatory capital inflation is, however, empirically most challenging. The calculation of a bank's regulatory capital depends on the underlying structure of its balance sheet and on difficult to observe variables, such as, for example, the appropriate valuation of goodwill and intangible assets. This makes it difficult to disentangle inflation motives from changes in regulatory capital due to the proper application of accounting standards. In a similar vein, it is hard to obtain direct evidence for regulatory forbearance on behalf of national authorities (Huizinga and Laeven, 2012). Thus, an ideal experiment would entail an exogenous shock across jurisdictions to the need of banks to raise their capital ratios, and then compare changes in the calculation of regulatory capital to a control group of banks without such motives.

The 2011 capital exercise, conducted by the European Banking Authority (EBA), uniquely provides such an empirical setting. The capital exercise raised the minimum required core tier 1 (CT1) capital ratio from $5 \%$ to $9 \%$ for a subset of European banks, while leaving requirements unchanged for other European banks. Although the EBA capital exercise was a uniform supranational regulatory intervention, national supervisors were ultimately in charge of approving the measures by which banks intended to increase their capital ratios (EBA, 2011a). This resulted in considerable national supervisory discretion and room to exercise forbearance regarding the approved measures taken by banks to reach the required capital ratio. The empirical setting of the EBA capital exercise naturally lends itself to a difference-in-differences research design. For our baseline analysis, we compare changes in the ratio of regulatory capital relative to book equity between banks subject to the 2011 capital exercise (CE banks) and banks not subject to the exercise (non-CE banks). ${ }^{3}$ If banks increase their regulatory capital without a commensurate increase in their book equity, then this implies a reduction in capital deductions which, in turn, increases the ratio of regulatory capital relative to book equity.

Our main findings are as follows. First, we find that CE banks (i.e., our treatment group) increased their ratio of regulatory capital to book equity by 10 percentage points relative to com-

\footnotetext{
${ }^{3}$ We adopt the following terminology: capital exercise (CE) banks are banks selected into the 2011 EBA capital exercise and therefore subject to the increase in capital requirements (treatment group); non-capital exercise (non$\mathrm{CE}$ ) banks are other European banks not selected into the EBA capital exercise and therefore not subject to the increase in capital requirements (control group).
} 
parable non-CE banks (i.e., our control group). The economic magnitude of this effect is substantial. The average CE bank increased its regulatory capital from 2010 to 2012 by 16.2 percent, but its book equity by only 6.1 percent. Thus, for the average CE bank more than half of the increase in regulatory capital came from a reduction in capital deductions, and not from an increase in book equity. Consistent with weakly capitalized banks having a stronger incentive to engage in capital inflation to pass the EBA capital exercise, these results are driven by banks with ex-ante lower capital ratios. We further calculate a "shadow regulatory capital ratio" (book equity over risk-weighted assets) and investigate how this ratio changed compared to banks' officially reported capital ratios (regulatory capital over risk-weighted assets). We find that $\mathrm{CE}$ banks would not have achieved a material improvement in their reported capitalization relative to control group banks if they had not inflated their levels of regulatory capital. ${ }^{4}$

The main objective of the capital exercise was to bolster confidence in the banking system by ensuring that banks are sufficiently capitalized to withstand unexpected losses. Thus, an increase in regulatory capital ratios should - in principle - reflect an increase in banks' safety and soundness. We therefore study the effect of the capital exercise on market- and accounting-based measures of bank risk. We find that changes in the CDS spreads of CE banks do not significantly differ from the CDS spread changes of control group banks, neither around the announcement date of the capital exercise nor between the start and end date of the capital exercise. Moreover, we find a reduction in the z-score of weakly capitalized CE banks between 2010 and 2012 relative to the control group, suggesting that the increase in regulatory capital ratios of CE banks did not reflect an improvement in their safety and soundness.

During the capital exercise, there was considerable heterogeneity in supervisory approaches across countries in Europe (Barth, Caprio, and Levine, 2013; Nouy, 2017). Our results thus far suggest that exercising discretion in the calculation of regulatory capital is undesirable from a prudential point of view and was fully understood by market participants. Supervisors should therefore be wary of regulatory capital inflation. However, national authorities might choose to be lenient on their domestic banks for a variety of reasons: they might be prone to regulatory capture and have a tendency to be too soft on their national champion banks (Goodhart, 2012; Schoenmaker,

\footnotetext{
${ }^{4}$ Note that, in principle, banks can also increase their capital ratios by reducing risk-weighted assets, as shown in Gropp, Mosk, Ongena, and Wix (2019). In this analysis, we abstract from changes in risk-weighted assets and focus on discretion in the calculation of the numerator of the capital ratio.
} 
2012; Haselmann, Singla, and Vig, 2018; Bruno and Carletti, 2019); they might want to minimize disruptions to the financial system and the real economy caused by bank failures (Brown and Dinç, 2011; Huizinga and Laeven, 2012; Walther and White, 2020); their actions might be constrained by political considerations and the electoral cycle (Brown and Dinç, 2005; Bian, Haselmann, Kick, and Vig, 2017); or government interventions in the banking sector might be infeasible due to fiscal budget constraints (Martynova, Perotti, and Suarez, 2019; Acharya, Borchert, Jager, and Steffen, 2020).

We document substantial heterogeneity across countries in the extent to which banks engaged in regulatory capital inflation, suggesting that national authorities played an important role. In particular, we find that regulatory capital inflation is more pronounced in countries where national supervisors wield more discretionary power to exercise leniency, ${ }^{5}$ and in countries where credit supply is expected to tighten. These findings are consistent with the idea that local economic circumstances incentivize national authorities to exert discretion and forbearance, with an eye on short-term economic considerations.

Our paper contributes to several strands of literature. First, our paper adds to the literature on regulatory capital arbitrage. While a large number of studies investigate how banks exercise discretion in the calculation of risk-weighted assets (Acharya, Engle, and Pierret, 2014; Mariathasan and Merrouche, 2014; Behn, Haselmann, and Vig, 2016; Plosser and Santos, 2018), the calculation of regulatory capital has received little attention so far. We contribute to this literature by investigating regulatory adjustments to bank capital as an important margin of discretion that banks exploit to inflate their regulatory capital ratios.

Second, our paper also relates to the literature on supervisory leniency and regulatory forbearance. Previous studies show that regulators and supervisors exercise forbearance by approving favorable regulations (Skinner, 2008), by allowing non-compliance of banks with existing regulations (Huizinga and Laeven, 2012), by implementing identical rules inconsistently (Agarwal, Lucca, Seru, and Trebbi, 2014), or by being less likely to close failing banks (Morrison and White, 2013; Brown and Dinç, 2011), with potentially adverse effects for the real economy (Gropp, Ongena, Rocholl, and Saadi, 2018). Such regulatory forbearance may arise from regulatory capture (Goodhart, 2012; Schoenmaker, 2012; Haselmann, Singla, and Vig, 2018; Bruno and Carletti, 2019), the

\footnotetext{
${ }^{5}$ As measured by the Official Supervisory Power index introduced by Barth, Caprio, and Levine (2013)
} 
attempt to avoid disruptions to the real economy and the financial system (Brown and Dinç, 2011; Huizinga and Laeven, 2012; Walther and White, 2020), political considerations (Brown and Dinç, 2005; Bian, Haselmann, Kick, and Vig, 2017), and fiscal constraints preventing interventions in the banking system (Martynova, Perotti, and Suarez, 2019; Acharya, Borchert, Jager, and Steffen, 2020). We contribute to this literature by documenting that national supervisors show discretionary leniency with regard to their own domestic banks' pursuit of regulatory capital inflation to pass a supranational recapitalization exercise.

Third, we add to the literature on centralized versus decentralized bank supervision (Dell'Ariccia and Marquez, 2006; Calzolari, Colliard, and Lóránth, 2019; Carletti, DellAriccia, and Marquez, 2020). ${ }^{6}$ Several studies show that local, national supervisors are more lenient than centralized, supranational supervisors in the day-to-day oversight of banks (Agarwal, Lucca, Seru, and Trebbi, 2014; Haselmann, Singla, and Vig, 2019b; Colliard, 2020). Our study shows how national authorities provide discretion to their domestic banks in response to a one-time uniform supranational intervention.

Finally, our results also inform the design and implementation of stress tests and banking supervision. Investigating the 2014 ECB's asset quality review, Abbassi, Iyer, Peydró, and Soto (2020) document that banks engage in "window-dressing" to pass stress tests by shedding riskier assets off the balance sheet before the stress test and reload them after successful compliance. Our findings show that, in order to pass stress tests, banks do not only embellish the asset side of their balance sheet, but also exploit discretion in the calculation of regulatory capital, with no substantial improvement in financial stability. One of the main objectives of the EU Single Supervisory Mechanism (SSM) is to harmonize supervisory practices. Although significant progress has been made, national authorities still have substantial room for national discretion (Nouy, 2017). Our results highlight that agency problems between supranational and national authorities can undermine the effectiveness of supranational regulation.

The remainder of the paper proceeds as follows. Section I discusses the institutional background of the EBA capital exercise and the rules governing the calculation of regulatory capital. Section II describes our empirical strategy and the data. Section III reports our main results. Robustness

\footnotetext{
${ }^{6}$ See also Ampudia, Beck, Beyer, Colliard, Leonello, Maddaloni, and Marques-Ibanez (2019) for a broader discussion of this issue.
} 
checks are presented in Section IV. Section V concludes.

\section{Institutional Background}

\section{A. The 2011 EBA Capital Exercise}

The 2011 capital exercise, conducted by the European Banking Authority (EBA), was announced on October 26, 2011, and required 61 European banks to reach and maintain a $9 \%$ core tier 1 (CT1) capital ratio by the end of June $2012 .{ }^{7}$ This constituted an economically significant increase compared to the previously required 5\%. Banks' inclusion into the capital exercise was determined by a country-specific selection rule based on bank size. In particular, for each country, the EBA included "banks in descending order of their market shares by total assets," such that the exercise covered "at least 50 percent of the national banking sectors in each EU Member State in terms of total consolidated assets as of end 2010" (EBA, 2011b). As the selection procedure was based on total assets as of year-end 2010, it was not influenced by bank-specific events in the months leading up to the exercise. Both the timing and the magnitude of this increase in capital requirements was unexpected. The capital exercise came only a few months after the EU-wide stress test in June 2011 and was described as a "quick-fire regulatory health check" (Halstrick and Framke, 2011). The Financial Times reported that the 9 percent requirement was "well beyond the current expectations of banks and analysts" (Atkins, Jenkins, and Spiegel, 2011).

Although the EBA capital exercise was a supranational regulatory intervention, national supervisors were ultimately in charge of approving the measures by which banks intended to increase their capital ratios (EBA, 2011a). CE banks were asked to submit their recapitalization plans to their respective national supervisory authorities, outlining how they intended to reach the set targets. The EBA did not specify enforcement actions related to their recommendations on how banks had to be recapitalized. This resulted in considerable discretion for national supervisors and room to exercise forbearance regarding the approved measures taken by banks to reach the required capital ratio.

\footnotetext{
${ }^{7}$ See Gropp, Mosk, Ongena, and Wix (2019) for a detailed discussion of the institutional features of the 2011 EBA capital exercise, and Mésonnier and Monks (2015), Blattner, Farinha, and Rebelo (2019), Degryse, Karapetyan, and Karmakar (2018), and Haselmann, Kick, Singla, and Vig (2019a) for other papers exploiting the 2011 EBA capital exercise as a quasi-natural experiment.
} 


\section{B. Regulatory Capital and Book Equity}

Just like banks' risk-weighted assets for regulatory purposes differ from book assets for financial reporting purposes, regulatory capital differs from book equity. This difference originates from the distinct objectives of financial reporting and prudential regulation. While the aim of financial reporting is to provide information about the economic performance and condition of businesses, the objective of prudential regulation is to promote the safety and soundness of banks and the banking system. The underlying principles of financial reporting and prudential banking regulation are therefore not always aligned (BCBS, 2015).

A bank's book equity mainly comprises common share capital and retained earnings. Regulatory adjustments to bank capital aim to reconcile the two approaches and deduct certain elements from a bank's book equity, which are considered less effective in absorbing losses. Examples include goodwill and intangible assets, unrealized gains and losses on available-for-sale securities, deferred tax assets, and holdings in other financial institutions. The table in Online Appendix 1 details the calculation of regulatory capital via the application of regulatory adjustments to book equity according to the official Basel disclosure template (BCBS, 2011). The table thus illustrates the complexity of the rules governing the calculation of regulatory capital.

During the capital exercise, the EBA recommended that "banks should first use private sources of funding to strengthen their capital position to meet the required target, including retained earnings, reduced bonus payments, [and] new issuances of common equity" (EBA, 2011a). In the final report on the capital exercise, however, the EBA stated that "other mitigating measures directly impacting banks' capital position [stemming] from lower deductions from CT1 capital (e.g. depreciation/disposal of goodwill and intangible assets)" (EBA, 2012) amounted to 25.5 billion euros, a significant amount compared to the 50 billion euros of core capital raised by EBA banks with a capital shortfall. This is consistent with anecdotal evidence from banks' annual reports. For example, Deutsche Bank reported in its 2012 financial report that its "Common Equity Tier 1 (formerly referred to as Core Tier 1 ) capital increased to $€ 38.0$ billion from $€ 36.3$ billion" and that

"the increase in [...] Tier 1 capital primarily reflected reduced capital deduction items" (Deutsche Bank, 2012). 


\section{Economic Mechanisms and Incentives}

In line with the goals of prudential regulation, regulatory adjustments to book equity intend to increase the quality of a bank's capital by deducting items that may not fulfill their loss-absorbing function at all times (BCBS, 2015). An increase in a bank's regulatory capital relative to its level of book equity could therefore - in principle - reflect an increase in capital quality. In this case, we would expect an increase in regulatory capital to be associated with an increase in a bank's capability to absorb losses and thus with a reduction in bank risk. On the other hand, banks faced with a sudden and substantial increase in capital requirements have a strong incentive to engage in regulatory capital arbitrage to boost their capital ratios. By doing so, they might be able to meet increased regulatory requirements without issuing costly equity or retaining additional earnings. Hence, these incentives are particularly strong for ex-ante weakly capitalized banks (Boyson, Fahlenbrach, and Stulz, 2016). However, if banks merely exploit discretion in the calculation of regulatory capital, their capitalization might improve "on paper", but without an associated improvement in safety and soundness. In this case, we would expect such regulatory capital inflation to not be associated with a reduction in bank risk.

While banks have an incentive to inflate their regulatory capital, national authorities might have an incentive to turn a blind eye or actively support such activities, thereby exercising regulatory forbearance. As documented in previous studies, national authorities are often keen on preserving their domestic national champions (Schoenmaker, 2012; Goodhart, 2012), either because of regulatory capture or to ensure financial stability (Haselmann, Singla, and Vig, 2018). To avoid disruptions to bank lending and the real economy (Huizinga and Laeven, 2012), supervisors might decide to forbear failing banks, especially when the banking sector is weak (Brown and Dinç, 2011), as it was the case in Europe during the time of the capital exercise. Moreover, when national authorities are fiscally constrained, they might prefer to "kick the can down the road" (Acharya, Borchert, Jager, and Steffen, 2020) and exercise forbearance to postpone costly capital injections (Martynova, Perotti, and Suarez, 2019). The implementation of the Basel framework in Europe granted national authorities substantial discretionary powers to exercise leniency towards their domestic banks (Maddaloni and Scopelliti, 2019). Therefore, national authorities might play an important role in the extent to which banks are able to engage in regulatory capital inflation. 


\section{Empirical Strategy and Data}

\section{A. Empirical Strategy}

Identifying whether banks exercise discretion in the calculation of regulatory capital to inflate their capital ratios is challenging in the absence of a control group unaffected by these motives. We address this empirical challenge by exploiting the 2011 EBA capital exercise as an exogenous shock to banks' capital requirements and thus banks' needs to increase their regulatory capital ratios. The setup of the capital exercise, whereby the EBA required a subset of European banks to reach a 9\% CET1 capital ratio by the end of June 2012, while leaving requirements unchanged for other European banks, naturally lends itself to a difference-in-differences research design. The EBA selected banks according to an explicit selection rule based on bank size and included "banks in descending order of their market shares by total assets," such that the exercise covered "at least $50 \%$ of the national banking sectors in each EU Member State in terms of total consolidated assets as of end of 2010" (EBA, 2011b). This country-specific selection threshold yields a considerable overlap in size and other variables between banks selected and not selected into the capital exercise, which allows us to control for bank-specific characteristics.

To measure regulatory capital inflation, we study changes in the ratio of a bank's regulatory capital relative to its book equity. If banks increase their regulatory capital without a commensurate increase in their book equity, then this implies a reduction in regulatory deductions and, therefore, an increase in the ratio of regulatory capital to book equity. To test whether the capital exercise incentivized banks to engage in regulatory capital inflation, we estimate the following baseline difference-in-differences regression specification:

$$
Y_{i}=\alpha+\beta \times \mathrm{CEB}_{i}+\delta \times\left(\mathrm{CEB}_{i} \times \mathrm{CT} 1 \mathrm{Ratio}_{2010, i}\right)+\sum_{k} \theta^{k} X_{i}^{k}+\gamma_{c}+\epsilon_{i}
$$

where $Y_{i}$ is the change in the ratio of regulatory core tier 1 (CT1) capital to total book equity from 2010 to 2012 , i.e. $\Delta$ (CT1 Capital/Total Book Equity $)_{2010-2012, i}$. Our treatment variable $C E B_{i}$ takes on the value of 1 for banks selected into the capital exercise, and 0 otherwise. As we expect weakly capitalized CE banks to have a stronger incentive to engage in regulatory capital inflation, we interact the treatment dummy with banks' pre-treatment capital ratios as of 2010. We control 
for the following bank characteristics $X_{i}^{k}$ as of 2010: log total assets, CT1 ratio, customer loans as a share of total assets, net interest income as a share of total operating revenue, depository funding as a share of total assets, and net income over total assets. Additionally, we include country fixed effects $\gamma_{c}$ and cluster standard errors at the country level.

\section{B. Data}

We use annual bank balance sheet data from the SNL Financial Company database. Our initial sample contains $61 \mathrm{CE}$ banks and 494 non-CE European commercial and savings banks from the SNL Financial universe. We follow the sample construction procedure in Gropp, Mosk, Ongena, and Wix (2019) and exclude all subsidiaries of CE banks, non-CE banks, and foreign banks, all banks which were acquired during the sample period, all banks which received capital injections during the pre-treatment period, and all banks with negative levels of equity. This sample construction procedure finally leaves us with a sample of $48 \mathrm{CE}$ banks (our treatment group) and 143 non-CE banks (our control group). The pre-and post-treatment periods in our analysis are 2010 and 2012, respectively, the years immediately before and after the capital exercise. All outcome variables are winsorized at the 5 percent level to reduce noise from extreme outliers. For our bank risk analysis, we obtain price data on five-year maturity CDS contracts on senior and junior bonds of European banks. During our sample period, CDS data are available for $45 \mathrm{CE}$ banks and 11 non-CE banks.

Table I shows summary statistics and mean comparisons for CE banks and non-CE banks as of 2010, the year immediately prior to the capital exercise. Due to the capital exercise being carried out on the largest banks in each country, the average capital exercise bank is about 18 times larger than the average non-capital exercise bank. We address potential identification concerns regarding bank size throughout our analysis and, in Section IV.B, conduct a number of robustness checks employing a matching estimation strategy.

[Table I about here]

The crucial identifying assumption of a DID estimator requires that the ratio of regulatory capital to book equity (our main outcome variable) would follow a parallel trend for treated banks and non-treated banks in absence of the capital exercise. Figure 1 shows the evolution of this ratio relative to 2010 for $\mathrm{CE}$ banks and non-CE banks. Prior to the capital exercise, the ratio of 
regulatory capital to book equity was stable for both groups of banks. From 2010 to 2012, however, banks in the capital exercise significantly increased their levels of regulatory capital relative to book equity, implying a substantial reduction in capital deductions around the EBA capital exercise. In contrast, the ratio remained unchanged for non-CE banks in the control group.

[Figure 1 about here]

\section{Results}

\section{A. Univariate Results}

We first provide univariate descriptive statistics how CE banks in our treatment group and non-CE banks in our control group adjusted their regulatory capital and book equity around the capital exercise. Table II reports the changes in total book equity, capital deductions, regulatory core tier 1 (CT1) capital, and in the ratio of regulatory capital to book equity between 2010 and 2012 for the two groups of banks. CE banks increased their regulatory capital by on average 16.2 percent around the capital exercise, and therefore by about the same magnitude as non-CE banks with 16.3 percent. This finding, however, masks important differences in how the two groups of banks achieved this. While non-CE banks increased their book equity by 16.4 percent, CE banks did so by only 6.1 percent. CE banks achieved their increase in regulatory capital to a substantial degree via a 23.1 percent reduction in capital deductions. Thus, for the average CE bank, more than half of the increase in regulatory capital stems form a reduction in capital deductions and not from an increase in book equity. CE banks therefore achieved a similar increase in regulatory capital as non-CE banks, even though they increased their book equity by 10.4 percentage points less. Consequently, for CE banks, the share of book equity counting towards regulatory capital increased by 8.7 percent from 2010 to 2012, while this ratio remained constant for non-CE banks over the same period.

[Table II about here] 


\section{B. Regulatory Capital Inflation}

While the graphical evidence in Figure 1 and the univariate descriptive statistics in Table II are suggestive that $\mathrm{CE}$ banks exercised discretion in the calculation of regulatory capital, these changes could conceivably be driven by other bank-specific factors. Table III therefore presents the estimation results of the difference-in-differences regression from Equation (1) in Section II. The first column provides the unconditional treatment effect of the capital exercise and shows that CE banks increased their regulatory capital relative to their book equity by 9.3 percentage points compared to non-CE banks. The second column additionally controls for 2010 pre-treatment levels of log total assets, CT1 ratios, deposits over total assets, loans over total assets, net interest income over total operating revenue, and net income over total assets. In this specification, CE banks increased their regulatory capital to book equity ratio by 7.4 percentage points compared to nonCE banks, alleviating concerns that our results are driven by either bank size, profitability, banks' business models, or funding strategies. The third column additionally includes country dummy variables and compares $\mathrm{CE}$ banks and non-CE banks within countries. In this specification, $\mathrm{CE}$ banks increased the regulatory capital to book equity ratio by 10 percentage points relative to non-CE banks.

[Table III about here]

As we expect weakly capitalized CE banks to have a stronger incentive to engage in regulatory capital inflation, the fourth column includes the interaction of the CEB dummy with banks' pretreatment capital ratios. ${ }^{8}$ Consistently, we find that a higher pre-treatment capitalization of CE banks leads to a significant reduction in regulatory capital inflation around the capital exercise. For CE banks, a one standard deviation increase in the pre-treatment CT1 capital ratio is associated with an additional 9 percentage points reduction in the ratio of regulatory capital to book equity. This result is consistent both with arbitrage-like behavior on behalf of banks, which is more pronounced for weakly capitalized banks (Boyson, Fahlenbrach, and Stulz, 2016), and with regulatory forbearance on behalf of national authorities, which are more likely to forbear weakly capitalized banks (Brown and Dinç, 2011; Acharya, Borchert, Jager, and Steffen, 2020).

\footnotetext{
${ }^{8}$ Lubberink (2014) reports that low solvency banks in the United States report values of Tier 1 regulatory capital that exceed book equity, benefiting from regulatory adjustments to inflate their capital ratios
} 
Finally, the fifth column examines whether banks' engagement in regulatory capital inflation is driven by bank size. Bigger banks tend to have, for example, more intangible assets and a larger trading book. This results in higher levels of capital deductions that can be adjusted to inflate regulatory capital ratios, providing large banks with more potential arbitrage opportunities to exploit. We find, however, that regulatory capital inflation of CE banks is not related to their size. The coefficient on the bank size interaction term is insignificant and, moreover, the magnitudes of the other coefficients do not change. This finding alleviates concerns that differences in bank size between $\mathrm{CE}$ banks and non-CE banks constitute a confounding factor in our analysis of regulatory capital inflation.

The objective of the capital exercise was to restore confidence in the EU banking sector by improving the capitalization of the largest European banks. In its final report on the capital exercise, the EBA (2012) stated that "the vast majority of the banks involved in the EBA capital exercise show a CT1 [capital ratio], as of end of June, above the $9 \%$ [...]", but also that "other mitigating measures directly impacting banks' capital position [stemming] from lower deductions from CT1 capital (e.g. depreciation/disposal of goodwill and intangible assets)" amounted to 25.5 billion euros, a significant amount compared to the 50 billion euros of core capital raised by EBA banks with a capital shortfall. To what extent was the increase in CT1 ratios of CE banks achieved by regulatory capital inflation as opposed to an increase in book equity? To investigate this question, we calculate a shadow capital ratio defined as a bank's level of book equity over its risk-weighted assets. This shadow ratio thus has the same denominator as the regulatory CT1 capital ratio and only differs in terms of the capital definition used in the numerator. We estimate the regression specification in Equation (1) with the changes in reported CT1 ratios and shadow capital ratios as the dependent variable, respectively.

Table IV reports the regression results of this analysis. The first two columns show that especially weakly capitalized CE banks significantly increased their reported CT1 ratios relative to non-CE banks around the capital exercise. However, as shown in the third and fourth column, this is not the case for their shadow capital ratios. All coefficients are statistically insignificant and considerably smaller in magnitude. Since the two ratios only differ in terms of the definition of capital used in the numerator (regulatory capital versus book equity), these results suggest that weakly capitalized CE banks would not have achieved a material improvement in their reported 
capitalization without engaging in regulatory capital inflation.

[Table IV about here]

\section{Regulatory Capital Inflation and Financial Stability}

Since the prudential goal of higher capital requirements is to improve a bank's ability to absorb losses, any increase in capital ratios should be associated with an increase in bank stability. However, if capital ratios only improve "on paper", either due to managerial discretion (i.e., arbitrage behavior on behalf of banks) or due to preferential regulatory treatment (i.e., forbearance on behalf of national authorities), then the riskiness of banks should not improve and remain unaffected. We therefore study the effect of the capital exercise on market- and accounting-based measures of bank risk.

We first investigate whether the capital exercise was associated with a change in the market's perception of bank risk. To that end, we conduct an event study and examine the reaction of CDS returns of $\mathrm{CE}$ banks and non-CE banks in a three-day time window around the announcement of the capital exercise on October 26, 2011. The first three columns in Panel A of Table V show that the announcement of the capital exercise did not reduce the CDS spread of CE banks. Column 4 of Panel A tests for differences in the reaction of CDS returns between stongly and weakly capitalized CE banks. As the capital exercise aimed to improve the capital positions of weakly capitalized banks, we should expect their CDS spreads to shrink after the announcement-consistent with a reduction in bank risk. Column 4, however, shows that this interaction coefficient is insignificant. We further investigate the change in CDS spreads between the start date (October 2011) and end date (June 2012) of the capital exercise. We do not find significant effects, neither on senior nor on junior CDS spreads.

[Table $\mathrm{V}$ about here]

Finally, Figure 2 plots the estimated difference in CDS spreads between CE and non-CE banks for each qurter over the period from 2011Q1 to 2012Q3. The figure illustrates that the CDS spreads of $\mathrm{CE}$ banks and non-CE banks follow a parallel trend in the quarters before the capital exercise and do not significantly diverge during and after the capital exercise. In summary, we do not find 
any evidence that the capital exercise was associated with a change in the market's perception of bank risk. ${ }^{9}$

[Figure 2 about here]

One drawback of this analysis is that CDS data are only available for a subset of $45 \mathrm{CE}$ banks and 11 non-CE banks in our sample. Therefore, in Panel B, we investigate an accounting-based measure of bank risk and estimate the regression specification from Equation (1) with the change in banks' z-scores from 2010 to 2012 as the outcome variable. We follow Beck, De Jonghe, and Schepens (2013) and calculate a bank's z-Score as:

$$
Z_{i}=\frac{R O A_{i}+\left(\frac{E}{A}\right)_{i}}{\sigma(R O A)_{i}}
$$

where $R O A$ is the return on assets, $E / A$ is the ratio of book equity to total assets, and $\sigma(R O A)$ is the standard deviation of the return on assets over a three-year rolling time window. The z-score measures a bank's distance to insolvency such that higher values indicate that the bank is more stable (Laeven and Levine, 2009).

Panel B of Table V reports the results for our z-Score analysis. The first three columns show that there was no increase in the z-Score of CE banks around the capital exercise and that the magnitude of the coefficient is negative, albeit statistically insignificant. The fourth column shows that especially for weakly capitalized banks, the z-Score even significantly decreased, indicating a higher probability of default and an increase in bank risk. This finding is consistent with our results in Table III that especially weakly capitalized banks inflated their levels of regulatory capital inflation to boost their capital ratios. ${ }^{10}$

In summary, our results are inconsistent with the notion that the increase in regulatory capital ratios of CE banks via reduced capital deductions is associated with an improvement of banks' safety and soundness. While CE banks improved their capitalization "on paper", this did not translate into a reduction of non-regulatory market- and accounting-based measures of bank risk.

\footnotetext{
${ }^{9}$ This is consistent with the evidence provided in Mésonnier and Monks (2015), who also report that the EBA capital exercise did not give rise to large changes in banks' CDS spreads.

${ }^{10}$ Our results are also in line with the findings of Bostandzic, Irresberger, Juelsrud, and Wei (2020) who show that the EBA capital exercise did not result in an improvement of various risk measures (i.e., Value-at-Risk, the inverse z-score, systematic risk, marginal expected shortfall, market-based leverage ratio, and SRISK) for banks in the capital exercise.
} 
Hence, regulatory capital inflation has at best no, and at worst detrimental effects on financial stability and is therefore undesirable from a prudential point of view.

\section{Regulatory Capital Inflation and Regulatory Forbearance}

The extent to which banks are able to engage in regulatory capital inflation likely depends on the leeway they are given by their regulatory and supervisory authorities. During the EBA capital exercise, banks had to submit their recapitalization plans to their respective National Supervisory Authorities (NSAs) which were ultimately in charge of approving the measures by which banks intended to increase their capital ratios (EBA, 2011a). Moreover, during the capital exercise, there was considerable heterogeneity in supervisory approaches across countries in Europe (Barth, Caprio, and Levine, 2013; Nouy, 2017). Our empirical setting, in which a sudden supranational regulatory intervention was implemented with considerable national discretion, uniquely allows us to investigate the degree and drivers of regulatory forbearance across countries.

We first document that there was substantial cross-country heterogeneity in the extent to which $\mathrm{CE}$ banks engaged in regulatory capital inflation. We estimate the following regression specification:

$$
Y_{i}=\alpha+\beta \times \mathrm{CEB}_{i}+\sum_{c} \delta^{c}\left(\mathrm{CEB}_{i} \times \mathrm{CY}_{c}\right)+\sum_{k} \theta^{k} X_{i}^{k}+\gamma_{c}+\epsilon_{i}
$$

where, as before, $Y_{i}$ is the change in the ratio of regulatory core tier 1 (CT1) capital to total book equity from 2010 to 2012; and $C E B_{i}$ is a dummy variable which takes on the value of 1 for banks selected into the capital exercise, and 0 otherwise. $C Y_{c}$ is a battery of country dummy variables, which take on the value 1 for country $c$, and 0 otherwise.

Figure 3 plots the estimated coefficients $\delta^{c}$ and the associated confidence intervals of Equation (3). Most notably, Italian and Portuguese banks inflated their regulatory capital by a considerably larger magnitude than banks in other European countries, as we discuss below. However, we also find a significant amount of capital inflation for banks in Austria, Germany, France, Norway, and Slovenia, although to a lesser degree.

[Figure 3 about here]

To investigate whether our overall results are exclusively driven by Italian and Portuguese 
banks, we re-estimate the regression specification from Equation (1) and include two interaction terms for banks headquartered in Italy and Portugal, respectively. Table VI reports the regression results of this analysis. Column 1 shows that the unconditional treatment effect for $\mathrm{CE}$ banks not based in Italy or Portugal is still statistically significant, albeit smaller in magnitude. However, including bank-level control variables in Column 2 renders the coefficient insignificant. Columns 3 and 4 investigate whether our results for weakly capitalized banks are also largely driven by Italian and Portuguese banks. In this analysis, all coefficients remain statistically significant, indicating that weakly capitalized banks across Europe inflated their regulatory capital around the capital exercise. Moreover, as in Table III, the interaction with total assets is again insignificant, indicating that our results are not driven by bank size.

[Table VI about here]

The results in Figure 3 and Table VI strongly suggest that country-specific factors are an important driver regarding the extent to which CE banks engage in regulatory capital inflation. We now explore the economic mechanisms behind this observed heterogeneity across countries. We start by collecting anecdotal evidence of national regulatory interventions around the time of the capital exercise which helped banks to boost their regulatory capital. Table VII provides an overview of measures implemented by national authorities which increased the capitalization of domestic banks. These policies helped banks to comply with the supranational requirements set by the EBA, consistent with Figure 3 and the results in Table VI.

The first form of regulatory forbearance are ad-hoc recapitalizations via CT1-eligible hybrid securities underwritten by the state. While these instruments are not part of a bank's book equity, they count towards regulatory capital. Both in Italy (Banca Monte dei Paschi di Siena) and Portugal (Banco BPI, Banco Comercial Português, Caixa Geral de Depósitos), the state acted as an underwriter for hybrid securities issued by CE banks, often explicitly citing the EBA capital exercise as the justification to boost banks' regulatory capital ratios. ${ }^{11}$

Second, besides direct capital support measures, several countries implemented specific regulations which resulted in an increase of banks' regulatory capital. One example is the tax treatment

\footnotetext{
${ }^{11}$ For example, the state aid application of Banco Comercial Português explicitly notes that "on 8 December 2011, the EBA published a Recommendation related to banks' recapitalisation needs" and that therefore "the BCP Group needed to raise substantial additional capital by 30 June 2012" (EC, 2012).
} 
of goodwill. The book values of intangible assets and goodwill are deducted from a bank's book equity to address the high level of uncertainty regarding their positive realizable value in times of stress or insolvency (BCBS, 2009). For many banks, these assets are large in magnitude relative to their regulatory capital (24\% for the CE banks in our sample as of 2010). Since the valuation of goodwill and intangible assets is subject to considerable accounting discretion (Beatty and Weber, 2006; Ramanna, 2008; Ramanna and Watts, 2012), they provide banks with substantial leeway to inflate their regulatory capital via an impairment of these assets, which lowers the amount of deductions from book equity. While such impairments are initially capital neutral, as they also reduce net income, banks can manage their regulatory capital via the devaluation of goodwill and intangible assets if such impairments are tax deductible. ${ }^{12}$ For example, in 2011, the Italian government enacted Law Decree 98/2011, allowing banks to boost their regulatory capital via the tax treatment of goodwill. In its 2011 Pillar 3 report, the Italian Bank Intesa Sanpaolo reported an increase in their regulatory capital ratio "from the realignment of goodwill envisaged by Law Decree no. 98/2011 (+52 basis points on Core Tier 1)" (Intesa Sanpaolo, 2011). There is also anecdotal evidence of this form of regulatory capital inflation for other countries. As reported by the Financial Times, the Spanish bank Banco Bilbao Vizcaya Argentaria (BBVA) wrote down " $€ 1.5$ billion on the value of its struggling US business" which "did not affect its cash position" but helped "boost its core capital by $€ 400$ million due to the tax treatment of goodwill" (Johnson, 2012). ${ }^{13}$

We next conduct a formal regression analysis regarding the drivers of the observed cross-country heterogeneity in regulatory capital inflation. National authorities might choose to be lenient on their domestic banks for a variety of reasons: they might be prone to regulatory capture and have a tendency to be too soft on their national champion banks (Goodhart, 2012; Schoenmaker, 2012; Haselmann, Singla, and Vig, 2018; Bruno and Carletti, 2019); they might want to minimize disruptions to the financial system and the real economy caused by bank failures (Brown and Dinç, 2011; Huizinga and Laeven, 2012; Walther and White, 2020); their actions might be constrained by political considerations and the electoral cycle (Brown and Dinç, 2005; Bian, Haselmann, Kick, and Vig, 2017); or government interventions in the banking sector might be infeasible due to fiscal

\footnotetext{
${ }^{12}$ Assume a goodwill impairment of $€ 1000$ and a tax rate of $20 \%$. The impairment will reduce capital deductions and therefore increase regulatory capital by $€ 1000$, while net income will decrease by only $€ 1000 \times(1-0.2)=€ 800$. The net effect on regulatory capital is therefore $€ 200$ due to the tax deductibility of the impairment charge.

${ }^{13}$ Online Appendix 2 discusses these forbearance measures in more detail and provides additional examples of how national authorities can use tax instruments to help their domestic banks to increase their regulatory capital ratios.
} 
budget constraints (Martynova, Perotti, and Suarez, 2019; Acharya, Borchert, Jager, and Steffen, 2020). In Table VIII, we examine these explanations by interacting our CEB treatment dummy with several country-level variables.

We first test for the regulatory capture of supervisors by national champion banks (Haselmann, Singla, and Vig, 2018). Column 1 of Table VIII includes the variable National Champion, which takes on the value of 1 if bank $i$ is the largest bank in country $c$ as of 2011 total assets, and 0 otherwise. We find a negative, but statistically insignificant relationship, suggesting that collusion between national authorities and the largest domestic banks did not play a role in the context of the capital exercise.

[Table VIII about here]

Second, we test whether supervisory power is associated with banks' engagement in capital inflation. We employ the Official Supervisory Power index from Barth, Caprio, and Levine (2013), which measures the degree to which a country's supervisory agency has the authority to take specific actions. While more powerful supervisors might be more capable to discipline banks, they might also use their power to forbear weak banks. Indeed, this index has been found in the literature to be associated with adverse outcomes, such as corruption in lending, and with no beneficial effects on financial stability (Beck, Demirgüç-Kunt, and Levine, 2006; Barth, Caprio, and Levine, 2013). Consistently, we find that CE banks in countries where supervisors wield more power were more likely to engage in regulatory capital inflation. This finding suggests that powerful national supervisors used their capacity to exercise leniency towards their national banks and provided them with leeway to exercise discretion in the calculation of regulatory capital.

Third, we investigate the role of national authorities' capacity for public intervention. Both theory (Martynova, Perotti, and Suarez, 2019) and recent empirical evidence (Acharya, Borchert, Jager, and Steffen, 2020) suggests that fiscally constrained governments might be more prone to engage in regulatory capital forbearance as they do not have the fiscal capacity to intervene in the banking sector. We follow Acharya, Borchert, Jager, and Steffen (2020) and measure the variable Fiscal Constraints using a country's current account balance as a percentage of nominal GDP. A higher current account balance indicates more fiscal room for government intervention. As shown in Column 3, we find no evidence for this mechanism in the context of the EBA capital exercise. 
Fourth, we study whether fears of a credit crunch induced national authorities to forbear their domestic banks, in an attempt to avoid adverse effects on the real economy. We employ data from the ECB's Bank Lending Survey and construct the variable Credit Standards, defined as the share of banks expecting a tightening in credit standards over the next quarter. The interaction term in Column 4 shows that regulatory capital inflation is more pronounced in countries in which banks (and therefore, arguably, regulators and supervisors) expect a near-term contraction of credit supply. This finding is consistent with the notion that national authorities might chose to be lenient on banks in bad times to avoid a financial panic and minimize disruptions to the real economy (Brown and Dinç, 2011; Huizinga and Laeven, 2012; Walther and White, 2020). While we do not analyze whether this regulatory forbearance helped to avert a credit crunch, Acharya, Borchert, Jager, and Steffen (2020) provide evidence that such forbearance causes banks, that remain weakly capitalized, to engage in zombie lending (Acharya, Eisert, Eufinger, and Hirsch, 2019).

Fifth, we test whether regulatory capital inflation might be driven by the election cycle. As governments have an incentive to delay bank failures until after elections (Brown and Dinç, 2005) and to avoid unpopular bail-outs prior to elections (Bian, Haselmann, Kick, and Vig, 2017), we would expect national authorities to be more lenient on banks before upcoming elections. To investigate this, we construct the variable Before Election, which takes on the value of 1 if the capital exercise took place 12 months before the next national congressional election, and 0 otherwise. As shown in Column 5, we find no evidence for such political considerations playing a role around the capital exercise.

Finally, we include all country-level variables jointly in a horse race regression in Columns 6 and 7 . The results confirm that regulatory capital inflation around the capital exercise was likely driven by powerful supervisors and the attempt to minimize disruptions to the real economy caused by a credit crunch. In contrast, regulatory capture by national champion banks, fiscal constraints of national authorities, and political considerations driven by the electoral cycle appear to play a minor role. The coefficient on Fiscal Constraints is only significant in Column 6 and the coefficient on National Champion even suggests that these banks were less engaged in regulatory capital inflation. 


\section{Robustness Checks}

\section{A. Placebo Treatment Periods}

If $\mathrm{CE}$ banks would systematically differ from non-CE banks with respect to characteristics relevant for capital deductions, we would expect to see differential changes in the ratio of regulatory capital to book equity between $\mathrm{CE}$ banks and non-CE banks also in other periods. To examine this possibility, we conduct two tests with placebo treatment periods before (2008-2010) and after (2012-2014) the 2011 EBA capital exercise. Table IX shows the results of this placebo exercise. For convenience of comparison, the first column of Table IX replicates our baseline result in the third column of Table and shows the treatment effect of the capital exercise from 2010 to 2012. The second and third column then compare the changes in regulatory deductions between CE banks and non-CE banks for the placebo periods from 2008 to 2010 and from 2012 to 2014, respectively. While there is strong evidence for regulatory capital inflation around the capital exercise, CE banks and non-CE banks exhibit no differential change in the ratio of regulatory capital to book equity during the two placebo periods. This alleviates concerns that CE banks and non-CE banks differ systematically with respect to characteristics relevant for regulatory deductions.

[Table IX about here]

\section{B. Matching Results}

For our main analysis, we rely on an OLS regression analysis. However, if the covariate distributions differ substantially by treatment status, then conventional regression methods can be sensitive to minor changes in the specification because of their heavy reliance on extrapolation. One approach to address this problem is the use of matching estimators which have favorable robustness properties with respect to a variety of data configurations (Imbens, 2014). Thus, we estimate the treatment effect of the capital exercise on regulatory capital inflation using the bias-corrected Abadie and Imbens (2011) matching estimator. Specifically, we adopt four different matching strategies based on Gropp, Mosk, Ongena, and Wix (2019). The full sample matching strategy matches four non-CE banks to each $\mathrm{CE}$ bank based on the six matching covariates using the full sample of $48 \mathrm{CE}$ banks and 144 non-CE banks. The overlap sample matching strategy matches one non-CE bank to each $\mathrm{CE}$ bank based on asset size only in the sample of banks which are 
larger than the smallest $\mathrm{CE}$ bank and smaller than the largest non-CE bank. The within-country matching strategy matches the two smallest CE banks and the two largest non-CE banks around the selection threshold within each country around. Finally, the within-region matching strategy matches $\mathrm{CE}$ banks to non-CE banks around the selection threshold within the same region (GIIPS countries and non-GIIPS countries). Online Appendix 3, which replicates Table 5 of Gropp, Mosk, Ongena, and Wix (2019), shows that the different matching strategies reduce differences in bank characteristics between treatment and control group banks. The third row in Table X provides the results of these matching exercises. Our results are robust and similar in magnitude to our regression results when using the full sample, the within-country, and the within-region matching strategy. While the treatment effect is not significant when employing the overlap sample matching strategy, the coefficient is very similar in magnitude. The associated p-value is 0.11 and the results are therefore borderline statistically significant at the $10 \%$ level.

[Table X about here]

\section{Robustness After Excluding Individual Countries and CE Banks}

Another concern is that our results are driven by individual countries or banks. Figure 3 shows that regulatory capital inflation of CE banks is more pronounced in Italy and Portugal. However, Columns 3 and 4 of Table VI show that the treatment effect is still positive and significant, even after including $\mathrm{CEB} \times$ Italy and $\mathrm{CEB} \times$ Portugal interaction terms. In Online Appendix 4, we replicate the results of Columns 3 and 4 in Table III for different subsamples, by excluding banks from each country and each CE bank individually. Our results are robust to this extensive battery of subsample robustness checks.

\section{Conclusion}

This paper studies how higher capital requirements introduced at the supranational affect regulatory capital of banks across countries. Exploiting the sudden increase in capital requirements during the 2011 EBA capital exercise, we find evidence that treated banks exercise discretion in the

calculation of regulatory capital, thereby inflating their regulatory capital without a commensurate increase in their book equity. This improvement in bank capitalization "on paper" did not translate 
into a reduction of non-regulatory market- and accounting-based measures of bank risk. We find that this form of regulatory capital inflation varies considerably across countries, suggesting that the leeway of banks to exercise discretion is provided to them by their own supervisory authorities. Regulatory capital inflation is more pronounced in countries with powerful supervisors and where a tightening of credit supply is expected in the near future. Our results suggest that national authorities forbear their domestic banks in order to minimize disruptions to bank lending and the real economy.

The aim of the ECB's Single Supervisory Mechanism (SSM), introduced in 2014, was to ensure a level playing field and the equal treatment of all supervised institutions. In our sample period, before the introduction of the SSM, discretionary powers on behalf of national supervisors resulted in a heterogeneous response of banks subject to the same supranational intervention. While the introduction of the SSM and the single European rulebook appear to have fostered a more consistent banking supervision across countries in Europe (Bruno and Carletti, 2019), there "is still room to arbitrage national rules" and concerns remain that "the single European rulebook is not yet single enough" (Nouy, 2017). 


\section{REFERENCES}

Abadie, Alberto, and Guido W. Imbens, 2011, Bias-corrected matching estimators for average treatment effects, Journal of Business \&5 Economic Statistics 29, 1-11.

Abbassi, Puriya, Rajkamal Iyer, José-Luis Peydró, and Paul E. Soto, 2020, Stressed banks? Evidence from the largest-ever supervisory review, Deutsche Bundesbank Discussion Paper 26/2020.

Acharya, Viral V., Lea Borchert, Maximilian Jager, and Sascha Steffen, 2020, Kicking the can down the road: Government interventions in the European banking sector, Review of Financial Studies forthcoming.

Acharya, Viral V., Tim Eisert, Christian Eufinger, and Christian Hirsch, 2019, Whatever it takes: The real effects of unconventional monetary policy, Review of Financial Studies 32, 3366-3411.

Acharya, Viral V., Robert Engle, and Diane Pierret, 2014, Testing macroprudential stress tests: The risk of regulatory risk weights, Journal of Monetary Economics 65, 36-53.

Agarwal, Sumit, David Lucca, Amit Seru, and Francesco Trebbi, 2014, Inconsistent regulators: Evidence from banking, Quarterly Journal of Economics 129, 889-938.

Ampudia, Miguel, Thorsten Beck, Andreas Beyer, Jean-Edouard Colliard, Agnese Leonello, Angela Maddaloni, and David Marques-Ibanez, 2019, The architecture of supervision, ECB Working Paper Series 2287.

Angeloni, Ignazio, 2014, The SSM sails past the starting line: Seeking high-quality supervision and level playing field, Speech London, 10 November 2014.

Atkins, Ralph, Patrick Jenkins, and Peter Spiegel, 2011, Europe's banks face 9\% capital rule, Financial Times October 11, 2011.

Barth, James R., Gerard Caprio, and Ross Levine, 2013, Bank regulation and supervision in 180 countries from 1999 to 2011, NBER Working Paper 18733.

BCBS, 2009, Strengthening the resilience of the banking sector, Consultative Document December 2009. 
BCBS, 2011, Definition of capital disclosure requirements, Consultative document December 2011.

BCBS, 2015, The interplay of accounting and regulation and its impact on bank behaviour: Literature review, Working Paper 28.

Beatty, Anne, and Joseph Weber, 2006, Accounting discretion in fair value estimates: An examination of sfas 142 goodwill impairments, Journal of Accounting Research 44, 257-288.

Beck, Thorsten, Olivier De Jonghe, and Glenn Schepens, 2013, Bank competition and stability: Cross-country heterogeneity, Journal of Financial Intermediation 22, 218-244.

Beck, Thorsten, Asli Demirgüç-Kunt, and Ross Levine, 2006, Bank supervision and corruption in lending, Journal of Monetary Economics 53, 2131-2163.

Behn, Markus, Rainer Haselmann, and Vikrant Vig, 2016, The limits of model-based regulation, ECB Working Paper Series 1928.

Bian, Bo, Rainer Haselmann, Thomas Kick, and Vikrant Vig, 2017, The political economy of bank bailouts, Mimeo .

Blattner, Laura, Luísa Farinha, and Francisca Rebelo, 2019, When losses turn into loans: the cost of undercapitalized banks, ECB Working Paper Series 2228.

Bostandzic, Denefa, Felix Irresberger, Ragnar Juelsrud, and Gregor Wei, 2020, Do capital requirements make banks safer? Evidence from a quasi-natural experiment, Leeds University Business School Working Paper 18-02.

Boyson, Nicole M., Rüdiger Fahlenbrach, and René M. Stulz, 2016, Why dont all banks practice regulatory arbitrage? Evidence from usage of trust-preferred securities, Review of Financial Studies 29, 1821-1859.

Brown, Craig O., and I. Serdar Dinç, 2005, The politics of bank failures: Evidence from emerging markets, Quarterly Journal of Economics 120, 1413-1444.

Brown, Craig O., and I. Serdar Dinç, 2011, Too many to fail? Evidence of regulatory forbearance when the banking sector is weak, Review of Financial Studies 24, 1378-1405. 
Bruno, Brunella, and Elena Carletti, 2019, The next SSM term: Supervisory challenges ahead, InDepth Analysis requested by the European Parliament's Committee on Economic and Monetary Affairs .

Calzolari, Giacomo, Jean-Edouard Colliard, and Gyongyi Lóránth, 2019, Multinational banks and supranational supervision, Review of Financial Studies 32, 2997-3035.

Carletti, Elena, Giovanni DellAriccia, and Robert Marquez, 2020, Supervisory incentives in a banking union, Management Science forthcoming.

Colliard, Jean-Edouard, 2020, Optimal supervisory architecture and financial integration in a banking union, Review of Finance 24, 129-161.

Degryse, Hans, Artashes Karapetyan, and Sudipto Karmakar, 2018, To ask or not to ask? Bank capital requirements and loan collateralization, CEPR Discussion Paper Series 13331.

Dell'Ariccia, Giovanni, and Robert Marquez, 2006, Competition among regulators and credit market integration, Journal of Financial Economics 79, 401-430.

Deutsche Bank, 2012, Financial report 2012 .

EBA, 2011a, Eba recommendation on the creation and supervisory oversight of temporary capital buffers to restore market confidence (EBA/REC/2011/1), December 8, 2011 .

EBA, 2011b, EU-wide stress test: Methodological note, March 18, 2011 .

EBA, 2012, Final report on the implementation of capital plans following the EBAs 2011 recommendation on the creation of temporary capital buffers to restore market confidence, october 3, 2012 October 2012.

EC, European Commission, 2012, SA.34724 Restructuring of Banco Comercial Português (BCP) Group Portugal, State Aid Cases https://ec.europa.eu/competition/elojade/isef/case_ details.cfm?proc_code=3_SA_34724.

Goodhart, Charles, 2012, Funding arrangements and burden sharing in banking resolution, In: Banking Union for Europe: Risks and Challenges Thorsten Beck (ed.). 
Gropp, Reint, Thomas Mosk, Steven Ongena, and Carlo Wix, 2019, Bank response to higher capital requirements: Evidence from a quasi-natural experiment, Review of Financial Studies $32,266-299$.

Gropp, Reint, Steven Ongena, Jörg Rocholl, and Vahid Saadi, 2018, The cleansing effect of banking crises, Mimeo .

Haldane, Andrew G., 2012, The dog and the frisbee, Speech given at the Federal Reserve Bank of Kansas City's 36th Economic Policy "The Changing Policy Landscape” Jackson Hole, Wyoming.

Haldane, Andrew G., 2013, Constraining discretion in bank regulation, Speech given at the Federal Reserve Bank of Atlanta Conference on "Maintaining financial stability: holding a tiger by the tail(s)", Federal Reserve Bank of Atlanta, Atlanta, 9 April 2013. .

Halstrick, Philipp, and Andreas Framke, 2011, Europe hits banks with tougher capital test, Reuters October 11, 2011.

Haselmann, Rainer, Thomas Kick, Shikhar Singla, and Vikrant Vig, 2019a, Capital regulation, market-making, and liquidity, Mimeo .

Haselmann, Rainer, Shikhar Singla, and Vikrant Vig, 2018, Political economy of financial regulation, Mimeo .

Haselmann, Rainer, Shikhar Singla, and Vikrant Vig, 2019b, Supranational supervision, Mimeo .

Huizinga, Harry, and Luc Laeven, 2012, Bank valuation and accounting discretion during a financial crisis, Journal of Financial Economics 106, 614-634.

Imbens, Guido W., 2014, Matching methods in practice: Three examples, NBER Working Paper Series 19959.

Intesa Sanpaolo, 2011, Basel 2 Pillar 3 Disclosures as at 31 December 2011 .

Johnson, Miles, 2012, BBVA takes EUR 1.5bn us writedown, Financial Times January 10, 2012.

Laeven, Luc, and Ross Levine, 2009, Bank governance, regulation, and risk taking, Journal of Financial Economics 93, 259-275. 
Lubberink, Martien, 2014, A primer on regulatory bank capital adjustments, Mimeo .

Maddaloni, Angela, and Alessandro D. Scopelliti, 2019, Rules and discretion(s) in prudential regulation and supervision: evidence from EU banks in the run-up to the crisis, ECB Working Paper Series 2284.

Mariathasan, Mike, and Ouarda Merrouche, 2014, The manipulation of basel risk-weights, Journal of Financial Intermediation 23, 300-321.

Martynova, Natalya, Enrico C. Perotti, and Javier Suarez, 2019, Bank capital forbearance, CEPR Discussion Paper 13617.

McKinsey, 2017, Bringing Basel IV into focus: How banks can mitigate 120 billion euro in capital requirements and avoid an ROE haircut., McKinsey $\&$ Company Risk Insights November 2017.

Mésonnier, Jean-Stéphane, and Allen Monks, 2015, Did the EBA capital exercise cause a credit crunch in the Euro area?, International Journal of Central Banking June 2015, 75-117.

Morrison, Alan D., and Lucy White, 2013, Reputational contagion and optimal regulatory forbearance, Journal of Financial Economics 110, 642-658.

Nouy, Danièle, 2017, Gaming the rules or ruling the game? How to deal with regulatory arbitrage, Speech at the 33rd SUERF Colloquium, Helsinki, 15 September 2017.

Plosser, Matthew C., and João A. C. Santos, 2018, Banks' incentives and inconsistent risk models, Review of Financial Studies 31, 2080-2112.

Ramanna, Karthik, 2008, The implications of unverifiable fair-value accounting: Evidence from the political economy of goodwill accounting, Journal of Accounting and Economics 45, 253-281.

Ramanna, Karthik, and Ross L. Watts, 2012, Evidence on the use of unverifiable estimates in required goodwill impairment, Review of Accounting Studies 17, 749-780.

Schoenmaker, Dirk, 2012, Banking supervision and resolution: The European dimension, Law and Financial Markets Review 6, 52-60.

Skinner, Douglas J., 2008, The rise of deferred tax assets in Japan: The role of deferred tax accounting in the Japanese banking crisis, Journal of Accounting and Economics 46, 218-239. 
Walther, Ansgar, and Lucy White, 2020, Rules versus discretion in bank resolution, Review of Financial Studies forthcoming. 


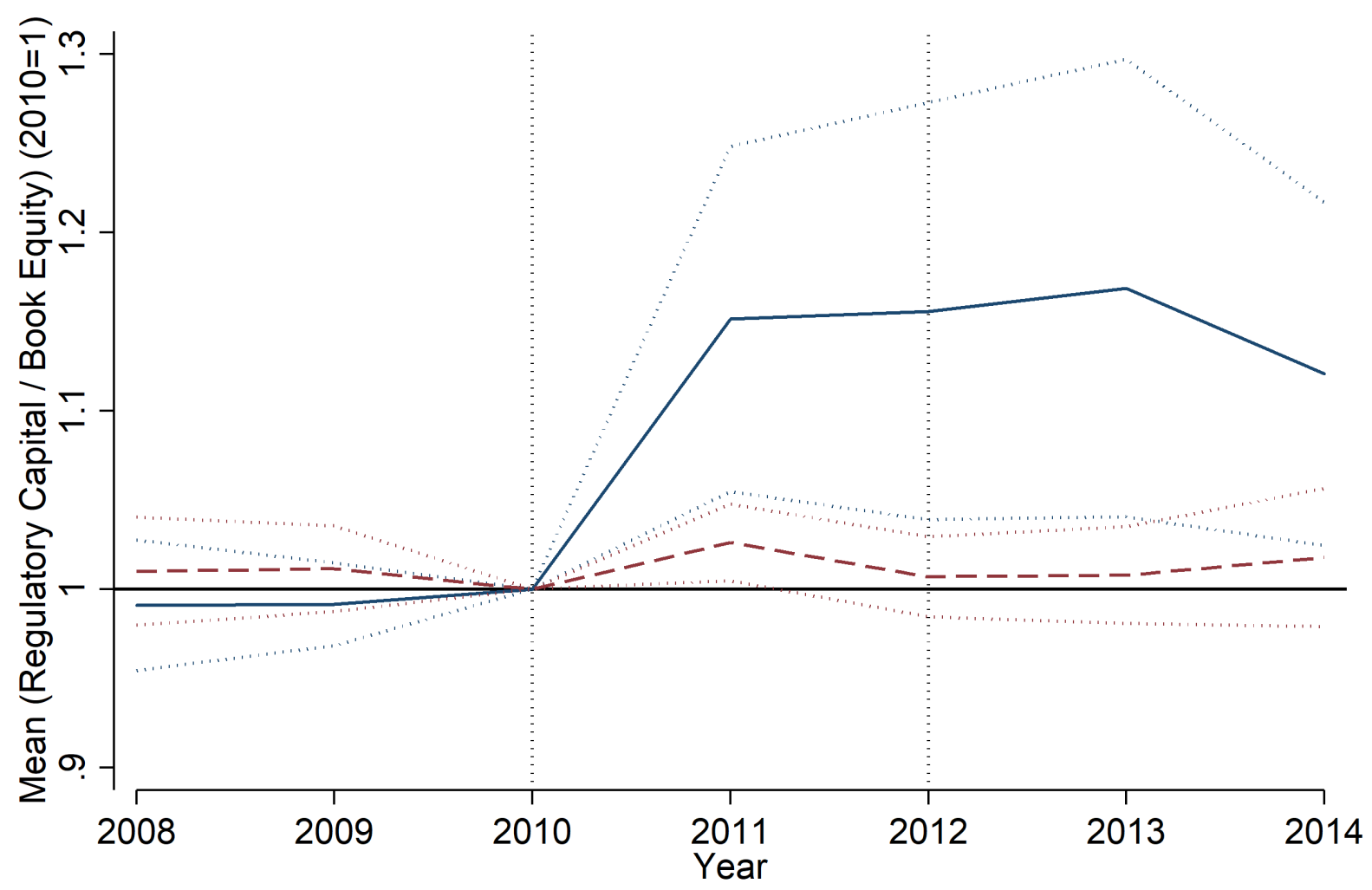

CE Banks - - - - Non-CE Banks

Figure 1. The Ratio of Regulatory Capital to Book Equity Over Time. Figure 1 shows the evolution of the mean ratio of regulatory core tier 1 (CT1) capital to total book equity over time for 48 capital exercise banks (CEB) (solid blue line) and 143 non-capital exercise banks (Non-CEB) (dashed red line), normalized to the value of 1 in 2010. The dotted lines indicate the 95 percent confidence intervals. The horizontal black line marks the value of 1 , indicating no change in the ratio. The two dashed vertical lines mark 2010 and 2012, the years immediately before and after the capital exercise. 


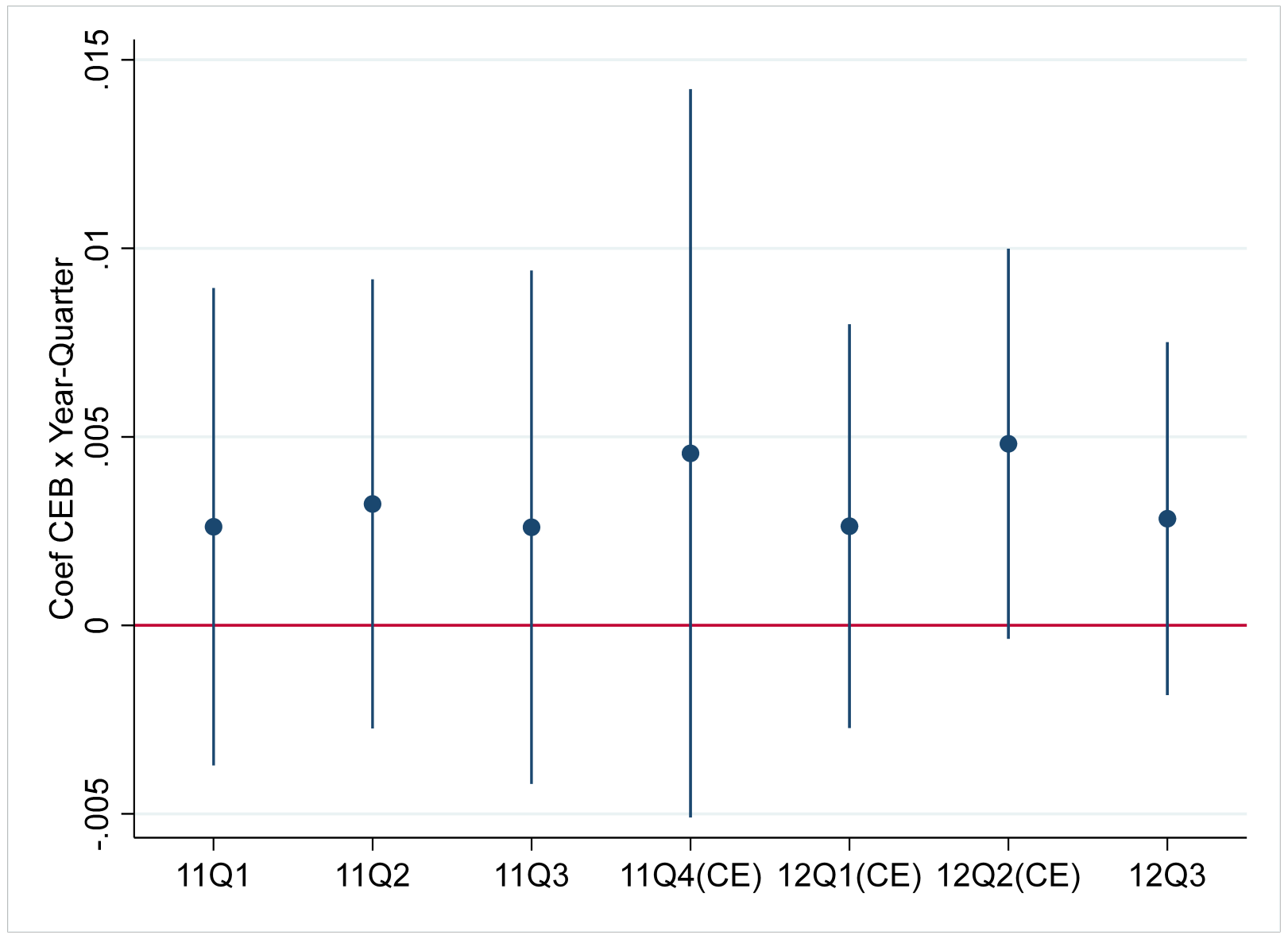

Figure 2. CDS Spreads of CE and Non-CE Banks Over Time. Figure 2 shows the estimated coefficients and confidence intervals of the specification: Senior CDS spread $=\beta_{1} \mathrm{CEB} \times$ Year - Quarter $+\mathrm{CY} \times$ YearQuarter FE + Bank FE $+\varepsilon$. Standard errors are clustered at the bank level. 


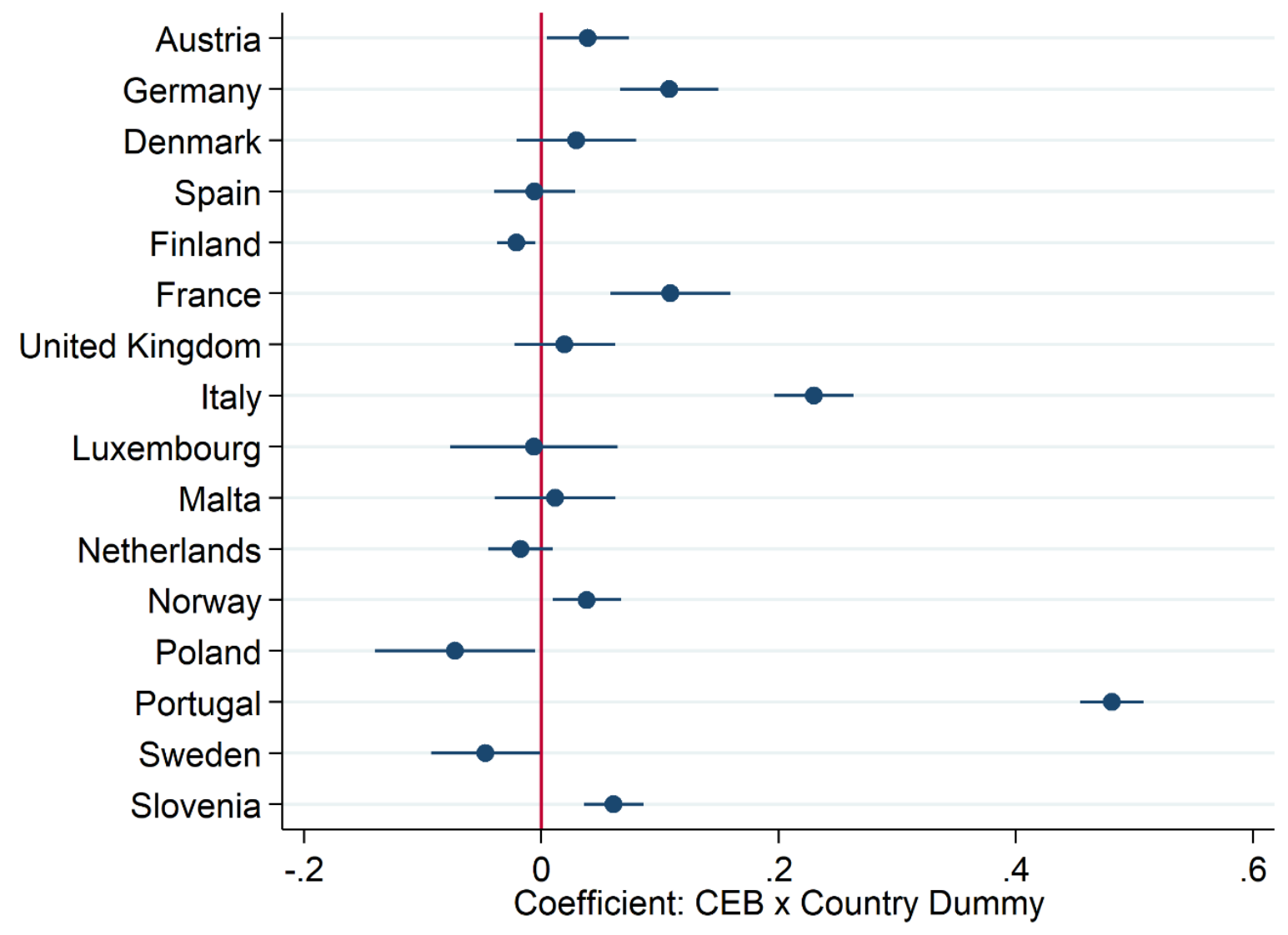

Figure 3. Cross-Country Heterogeneity in Regulatory Capital Inflation. Figure 3 plots the estimated coefficients $\delta^{c}$ and the associated confidence intervals of Equation (3) in Section III.D. The dependent variable is the change in the ratio of regulatory core tier 1 (CT1) capital to total book equity from 2010 to 2012 . The variable $\mathrm{CEB}_{i}$ takes on the value of 1 for banks selected into the capital exercise, and 0 otherwise; and $C Y_{c}$ is a battery of country dummy variables, which takes on the value 1 for country $c$, and 0 otherwise. We control for the following bank characteristics $X_{i}^{k}$ as of 2010: log total assets, CT1 ratio, customer loans as a share of total assets, net interest income as a share of total operating revenue, depository funding as a share of total assets, and net income over total assets. Standard errors are clustered at the country level. 


\section{Table I \\ Descriptive Statistics}

Table I provides summary statistics and mean comparisons for bank characteristics of 48 capital exercise banks (CEB) and 143 non-capital exercise banks (Non-CEB). "Log TA", "CT1 Ratio", "Deposits / TA", "Loans / TA", "NII / Op.Rev.", and "Net Income / TA" denote the logarithm of total assets, the core tier 1 (CT1) capital ratio, total deposits as a share of total assets, customer loans as a share of total assets, net interest income as a share of total operating revenue, and net income over total assets as of 2010, respectively. We test for differences in means using Welch's t-test. ${ }^{*},{ }^{* *}$, and ${ }^{* * *}$ indicate statistical significance at the $10 \%, 5 \%$, and $1 \%$ levels, respectively.

\begin{tabular}{|c|c|c|c|c|c|c|c|}
\hline & \multicolumn{3}{|c|}{$\mathrm{CEB}$} & \multicolumn{3}{|c|}{ Non-CEB } & \multirow[t]{2}{*}{$\Delta$ Mean } \\
\hline & Mean & Median & $\mathrm{SD}$ & Mean & Median & $\mathrm{SD}$ & \\
\hline Log TA & 5.26 & 5.21 & 1.46 & 2.00 & 2.21 & 1.58 & $3.27^{* * *}$ \\
\hline CT1 Ratio (in \%) & 9.86 & 9.21 & 3.12 & 11.43 & 10.64 & 4.99 & $-1.57^{* * *}$ \\
\hline Deposits / TA (in \%) & 40.93 & 40.47 & 15.59 & 55.46 & 56.25 & 20.49 & $-14.53^{* * *}$ \\
\hline Loans / TA (in \%) & 56.73 & 60.03 & 15.65 & 66.53 & 70.59 & 17.72 & $-9.80^{* * *}$ \\
\hline NII / Op. Rev. (in \%) & 60.42 & 57.94 & 14.86 & 67.65 & 68.97 & 22.59 & $-7.23^{* *}$ \\
\hline Net Income / TA (in \%) & 0.39 & 0.40 & 0.43 & 0.41 & 0.29 & 0.54 & -0.02 \\
\hline
\end{tabular}


Table II

\section{Univariate Results}

Table II presents the mean values of total book equity, capital deductions, regulatory core tier 1 (CT1) capital, and the ratio of regulatory capital to book equity for 48 capital exercise banks (CEB) and 143 non-capital exercise banks (Non-CEB) for the years 2010 and 2012, as well as mean percentage changes of these variables. Difference values are winsorized at the $5 \%$ level. The last column tests for differences-in-differences using Welch's t-test. ${ }^{*},{ }^{* *}$, and ${ }^{* * *}$ indicate statistical significance at the $10 \%, 5 \%$, and $1 \%$ levels, respectively.

\begin{tabular}{|c|c|c|c|c|c|c|c|}
\hline \multirow[b]{2}{*}{ Variable } & \multicolumn{3}{|c|}{ CEB } & \multicolumn{3}{|c|}{ Non-CEB } & \multirow[t]{2}{*}{ DID } \\
\hline & 2010 & 2012 & $\Delta \%$ & 2010 & 2012 & $\Delta \%$ & \\
\hline Book Equity & 23.08 & 24.25 & $6.06^{* *}$ & 1.39 & 1.59 & $16.44^{* * *}$ & $-10.37^{* * *}$ \\
\hline Capital Deductions & 7.34 & 6.03 & $-23.10^{* * *}$ & 0.25 & 0.28 & $12.52^{* *}$ & $-35.62^{* * *}$ \\
\hline CT1 Capital & 15.74 & 18.22 & $16.21^{* * *}$ & 1.13 & 1.30 & $16.32^{* * *}$ & -0.11 \\
\hline CT1 Capital / Book Equity (in \%) & 77.53 & 84.79 & $8.65^{* * *}$ & 88.36 & 87.68 & -0.65 & $9.30^{* * *}$ \\
\hline
\end{tabular}


Table III

\section{Changes in the Ratio of Regulatory Capital to Book Equity}

Table III presents the estimation results of the change in the ratio of regulatory capital to book equity from Equation (1) in Section II.A:

$$
Y_{i}=\alpha+\beta \times \mathrm{CEB}_{i}+\delta \times\left(\mathrm{CEB}_{i} \times \mathrm{CT} 1 \mathrm{Ratio}_{2010, i}\right)+\sum_{k} \theta^{k} X_{i}^{k}+\gamma_{c}+\epsilon_{i}
$$

where the dependent variable $Y_{i}$ is the change in the ratio of regulatory core tier 1 (CT1) capital to total book equity from 2010 to 2012, i.e. $\Delta$ (CT1 Capital/Total Book Equity) ${ }_{2010-2012, i}$. The variable $C E B_{i}$ takes on the value of 1 for banks selected into the capital exercise, and 0 otherwise. We control for the following bank characteristics $X_{i}^{k}$ as of 2010: $\log$ total assets, CT1 ratio, customer loans as a share of total assets, net interest income as a share of total operating revenue, depository funding as a share of total assets, and net income over total assets. $\gamma_{c}$ denote country fixed effects. Standard errors are clustered at the country level. ${ }^{*}, * *$, and $* * *$ indicate statistical significance at the $10 \%, 5 \%$, and $1 \%$ levels, respectively.

\begin{tabular}{|c|c|c|c|c|c|}
\hline Dependent variable & \multicolumn{5}{|c|}{$\Delta(\text { Regulatory Capital/Book Equity })_{2010-2012}$} \\
\hline CEB & $\begin{array}{l}0.093^{* *} \\
(0.034)\end{array}$ & $\begin{array}{c}0.074^{*} \\
(0.041)\end{array}$ & $\begin{array}{l}0.100^{* *} \\
(0.045)\end{array}$ & $\begin{array}{c}0.394^{* * *} \\
(0.101)\end{array}$ & $\begin{array}{c}0.439^{* *} \\
(0.156)\end{array}$ \\
\hline CEB $\times$ CT1 Ratio 2010 & & & & $\begin{array}{c}-0.032^{* * *} \\
(0.008)\end{array}$ & $\begin{array}{c}-0.032^{* * *} \\
(0.008)\end{array}$ \\
\hline CEB $\times$ Log Total Assets 2010 & & & & & $\begin{array}{l}-0.008 \\
(0.013)\end{array}$ \\
\hline Log Total Assets 2010 & & $\begin{array}{c}0.002 \\
(0.006)\end{array}$ & $\begin{array}{c}-0.003 \\
(0.008)\end{array}$ & $\begin{array}{c}0.001 \\
(0.008)\end{array}$ & $\begin{array}{c}0.002 \\
(0.007)\end{array}$ \\
\hline CT1 Ratio 2010 & & $\begin{array}{c}-0.004^{* *} \\
(0.002)\end{array}$ & $\begin{array}{l}-0.001 \\
(0.001)\end{array}$ & $\begin{array}{l}-0.000 \\
(0.001)\end{array}$ & $\begin{array}{l}-0.000 \\
(0.001)\end{array}$ \\
\hline (Total Deposits/TA) 2010 & & $\begin{array}{l}-0.000 \\
(0.000)\end{array}$ & $\begin{array}{l}-0.000 \\
(0.000)\end{array}$ & $\begin{array}{l}-0.000 \\
(0.000)\end{array}$ & $\begin{array}{l}-0.000 \\
(0.000)\end{array}$ \\
\hline (Customer Loans/TA) 2010 & & $\begin{array}{c}0.000 \\
(0.001)\end{array}$ & $\begin{array}{c}0.001 \\
(0.001)\end{array}$ & $\begin{array}{c}0.001 \\
(0.001)\end{array}$ & $\begin{array}{c}0.000 \\
(0.001)\end{array}$ \\
\hline (Net Int. Inc./Op.Rev) 2010 & & $\begin{array}{c}-0.001 \\
(0.000)\end{array}$ & $\begin{array}{l}-0.000 \\
(0.001)\end{array}$ & $\begin{array}{l}-0.000 \\
(0.001)\end{array}$ & $\begin{array}{l}-0.000 \\
(0.001)\end{array}$ \\
\hline (Net Income/TA) 2010 & & $\begin{array}{c}0.021 \\
(0.014)\end{array}$ & $\begin{array}{c}0.022 \\
(0.015)\end{array}$ & $\begin{array}{c}0.028^{*} \\
(0.014)\end{array}$ & $\begin{array}{l}0.028 * \\
(0.014)\end{array}$ \\
\hline Country FE & & & Yes & Yes & Yes \\
\hline $\begin{array}{l}\mathrm{N} \\
R^{2}\end{array}$ & $\begin{array}{c}191 \\
0.129\end{array}$ & $\begin{array}{c}191 \\
0.176\end{array}$ & $\begin{array}{c}191 \\
0326\end{array}$ & $\begin{array}{c}191 \\
0.401\end{array}$ & $\begin{array}{c}191 \\
0.402\end{array}$ \\
\hline
\end{tabular}




\section{Table IV \\ Changes in Capital Ratios and Shadow Capital Ratios}

Table IV presents the estimation results of the change in capital ratios (CT1 capital over riskweighted assets) and shadow capital ratios (total book equity over risk-weighted assets) from the following regression specification:

$$
Y_{i}=\alpha+\beta \times \mathrm{CEB}_{i}+\delta \times\left(\mathrm{CEB}_{i} \times \mathrm{CT} 1 \mathrm{Ratio}_{2010, i}\right)+\sum_{k} \theta^{k} X_{i}^{k}+\gamma_{c}+\epsilon_{i}
$$

where the dependent variable $Y_{i}$ is either the change in the CT1 capital ratio (Columns 1 and 2) or the change in the shadow capital ratio (Columns 3 and 4) from 2010 to 2012. The variable $C E B_{i}$ takes on the value of 1 for banks selected into the capital exercise, and 0 otherwise. We control for the following bank characteristics $X_{i}^{k}$ as of 2010: log total assets, CT1 ratio, customer loans as a share of total assets, net interest income as a share of total operating revenue, depository funding as a share of total assets, and net income over total assets. $\gamma_{c}$ denote country fixed effects. Standard errors are clustered at the country level. ${ }^{*},{ }^{* *}$, and ${ }^{* * *}$ indicate statistical significance at the $10 \%$, $5 \%$, and $1 \%$ levels, respectively.

\begin{tabular}{|c|c|c|c|c|}
\hline \multirow[b]{2}{*}{ CEB } & \multicolumn{2}{|c|}{$\Delta(\mathrm{CT} 1 \text { Capital/RWA })_{2010-2012}$} & \multicolumn{2}{|c|}{$\Delta(\mathrm{TE} / \mathrm{RWA})_{2010-2012}$} \\
\hline & $\begin{array}{c}1.003 \\
(0.781)\end{array}$ & $\begin{array}{l}3.213^{* *} \\
(1.343)\end{array}$ & $\begin{array}{c}0.300 \\
(0.742)\end{array}$ & $\begin{array}{l}-0.156 \\
(1.450)\end{array}$ \\
\hline CEB × CT1 Ratio 2010 & & $\begin{array}{c}-0.238^{*} \\
(0.122)\end{array}$ & & $\begin{array}{c}0.049 \\
(0.163)\end{array}$ \\
\hline Bank-Level Controls & Yes & Yes & Yes & Yes \\
\hline Country FE & Yes & Yes & Yes & Yes \\
\hline $\mathrm{N}$ & 191 & 191 & 190 & 190 \\
\hline$R^{2}$ & 0.306 & 0.322 & 0.207 & 0.208 \\
\hline
\end{tabular}




\section{Table V \\ The EBA Capital Exercise and Bank Risk}

Table 5 presents the estimation results for the following regression specification:

$$
Y_{i}=\alpha+\beta \times \mathrm{CEB}_{i}+\delta \times\left(\mathrm{CEB}_{i} \times \mathrm{CT} 1 \mathrm{Ratio}_{2010, i}\right)+\sum_{k} \theta^{k} X_{i}^{k}+\gamma_{c}+\epsilon_{i}
$$

where, in Panel A, the dependent variable $Y_{i}$ is the 3 -day cumulative CDS return around the announcement of the capital exercise on October 26 (Columns 1-4) and the change in senior and junior CDS spreads between October 2011 and June 2012 (Columns 5 and 6). In Panel B, the dependent variable is the change in banks' z-Scores between 2010 and 2012 . The variable $C E B_{i}$ takes on the value of 1 for banks selected into the capital exercise, and 0 otherwise. We control for the same bank characteristics as in the previous tables. $\gamma_{c}$ denote country fixed effects. Standard errors are clustered at the country level. * ${ }^{* *}$, and ${ }^{* * *}$ indicate statistical significance at the $10 \%$, $5 \%$, and $1 \%$ levels, respectively.

\begin{tabular}{|c|c|c|c|c|c|c|}
\hline \multicolumn{7}{|l|}{ Panel A. CDS Spreads. } \\
\hline & \multicolumn{4}{|c|}{ CDS Returns: October 26, 2011} & \multicolumn{2}{|c|}{$\begin{array}{l}\triangle \mathrm{CDS}: \text { Oct11-Jun12 } \\
\triangle \mathrm{CDS}^{S E N} \triangle \mathrm{CDS}^{S U B}\end{array}$} \\
\hline CEB & $\begin{array}{r}-8.44^{*} \\
(3.92)\end{array}$ & $\begin{array}{c}6.41 \\
(6.78)\end{array}$ & $\begin{array}{c}4.90 \\
(6.90)\end{array}$ & $\begin{array}{l}-19.41 \\
(41.03)\end{array}$ & $\begin{array}{c}-38.98 \\
(130.33)\end{array}$ & $\begin{array}{c}62.89 \\
(240.51)\end{array}$ \\
\hline CEB × CT1 Ratio 2010 & & & & $\begin{array}{c}2.91 \\
(4.88)\end{array}$ & $\begin{array}{c}15.96 \\
(17.89)\end{array}$ & $\begin{array}{c}-2.47 \\
(24.25)\end{array}$ \\
\hline $\begin{array}{l}\text { Bank-Level Controls } \\
\text { Country FE }\end{array}$ & & YES & $\begin{array}{l}\text { YES } \\
\text { YES }\end{array}$ & $\begin{array}{l}\text { YES } \\
\text { YES }\end{array}$ & $\begin{array}{l}\text { YES } \\
\text { YES }\end{array}$ & $\begin{array}{l}\text { YES } \\
\text { YES }\end{array}$ \\
\hline $\begin{array}{l}\mathrm{N} \\
R^{2}\end{array}$ & $\begin{array}{c}53 \\
0.03\end{array}$ & $\begin{array}{c}53 \\
0.28\end{array}$ & $\begin{array}{c}53 \\
0.44\end{array}$ & $\begin{array}{c}53 \\
0.46\end{array}$ & $\begin{array}{c}51 \\
0.68\end{array}$ & $\begin{array}{c}41 \\
0.68\end{array}$ \\
\hline \multicolumn{7}{|l|}{ Panel B. Z-Scores. } \\
\hline & \multicolumn{4}{|c|}{$\Delta$ Z-Score $2010-2012$} & & \\
\hline $\begin{array}{l}\text { CEB } \\
\text { CEB } \times \text { CT1 Ratio } 2010\end{array}$ & $\begin{array}{l}-2.04^{*} \\
(1.17)\end{array}$ & $\begin{array}{l}-1.85 \\
(1.12)\end{array}$ & $\begin{array}{l}-1.25 \\
(2.02)\end{array}$ & $\begin{array}{c}-8.86^{* * *} \\
(2.63) \\
0.82^{* * *} \\
(0.22)\end{array}$ & & \\
\hline $\begin{array}{l}\text { Bank-Level Controls } \\
\text { Country FE }\end{array}$ & & YES & $\begin{array}{l}\text { YES } \\
\text { YES }\end{array}$ & $\begin{array}{l}\text { YES } \\
\text { YES }\end{array}$ & & \\
\hline $\begin{array}{l}\mathrm{N} \\
R^{2}\end{array}$ & $\begin{array}{l}190 \\
0.02\end{array}$ & $\begin{array}{l}190 \\
0.05\end{array}$ & $\begin{array}{l}190 \\
0.20\end{array}$ & $\begin{array}{l}190 \\
0.21\end{array}$ & & \\
\hline
\end{tabular}




\section{Table VI \\ Regulatory Capital Inflation Across Countries}

Table VI presents the estimation results of the following regression specification:

$$
\begin{aligned}
Y_{i}=\alpha+\beta \times \mathrm{CEB}_{i} & +\delta \times\left(\mathrm{CEB}_{i} \times \mathrm{CT} 1 \mathrm{Ratio}_{2010, i}\right) \\
& +\gamma^{I T}\left(\mathrm{CEB}_{i} \times \text { Italy }\right) \\
& +\gamma^{P T}\left(\mathrm{CEB}_{i} \times \text { Portugal }\right) \\
& +\sum_{k} \theta^{k} X_{i}^{k}+\gamma_{c}+\epsilon_{i}
\end{aligned}
$$

where the dependent variable $Y_{i}$ is the change in the ratio of regulatory core tier 1 (CT1) capital to total book equity from 2010 to 2012 , i.e. $\Delta$ (CT1 Capital/Total Book Equity) ${ }_{2010-2012, i}$. The variable $C E B_{i}$ takes on the value of 1 for banks selected into the capital exercise, and 0 otherwise. Italy and Portugal are dummy variables which take on the value of 1 for Italian and Portuguese banks, respectively, and 0 otherwise. We control for the following bank characteristics $X_{i}^{k}$ as of 2010: log total assets, CT1 ratio, customer loans as a share of total assets, net interest income as a share of total operating revenue, depository funding as a share of total assets, and net income over total assets. $\gamma_{c}$ denote country fixed effects. Standard errors are clustered at the country level. *, $* *$, and $* * *$ indicate statistical significance at the $10 \%, 5 \%$, and $1 \%$ levels, respectively.

Dependent variable

CEB

CEB × CT1 Ratio 2010

CEB $\times$ Log Total Assets 2010

$\mathrm{CEB} \times$ Italy

$\mathrm{CEB} \times$ Portugal

Bank-Level Controls

Country FE

$\mathrm{N}$

$R^{2}$

$\Delta$ (Regulatory Capital/Book Equity $)_{2010-2012}$

$0.050^{* *}$

(0.021)

$$
(0.025)
$$

$0.187^{* * *}$

(0.021)

$0.450^{* * *}$

(0.021)

Yes
191
0.46
$0.199^{* * *}$

(0.019)

$0.441^{* * *}$

(0.015)

Yes

Yes

191

0.47
$0.218^{* * *}$

$(0.065)$

$-0.018^{* * *}$

(0.006)

$0.232^{* * *}$

(0.071)

$-0.019^{* * *}$

(0.005)

$-0.002$

(0.006)

$0.145^{* * *}$

$0.396^{* * *}$

(0.017)

(0.016)

Yes

Yes

191

0.49 


\section{Table VII \\ Regulatory Forbearance: Anecdotal Evidence}

Table VII presents anecdotal evidence on measures implemented by national authorities around the EBA capital exercise to increase the capitalization of domestic banks. For each measure, the table lists the country and the date, provides a short description, and, where applicable, refers to the national law or decree in which the measure was introduced. Online Appendix 2 provides a more detailed discussion on some of these policies.

\begin{tabular}{llll}
\hline \hline Country & Date & Description & Reference \\
& & & \\
Italy & Jul 6, 2012 & New instruments eligible as CT1 capital & Decree 95 \\
Italy & Jul 6, 2012 & Hybrid capital injection Banca MPS & \\
Italy & Jul 17,2011 & Tax treatment of goodwill & Decree 98/2011 \\
Italy & Dec 22,2011 & Conversion of DTAs to tax credits & Decree 201 \\
Portugal & Jan 11,2012 & Amendment recapitalization scheme & Law 4/2012 \\
Portugal & Jun 29,2012 & Hybrid capital injection Banco BPI & \\
Portugal & Jun 29,2012 & Hybrid capital injection Banco Comercial & \\
Portugal & Jun 28,2012 & Hybrid capital injection CGD & \\
Slovenia & May 16,2012 & Hybrid capital injection Nova Ljublj. Banka & \\
Slovenia & Dec 5, 2012 & Hybrid capital injection Nova Kreditna Banka & \\
& & & \\
\hline \hline
\end{tabular}


Table VIII

\section{Cross-Country Determinants of Regulatory Capital Inflation}

Table VIII presents the estimation results of the following specification:

$$
Y_{i}=\alpha+\beta \times \mathrm{CEB}_{i}+\delta \times\left(\mathrm{CEB}_{i} \times \mathrm{CT1} \operatorname{Ratio}_{2010, i}\right)+\sum_{c} \kappa^{c}\left(\mathrm{CEB}_{i} \times \mathrm{CY} \text { Characteristic }_{c}\right)+\sum_{k} \theta^{k} X_{i}^{k}+\gamma_{c}+\epsilon_{i}
$$

where the dependent variable $Y_{i}$ is the change in the ratio of regulatory core tier 1 (CT1) capital to total book equity from 2010 to 2012. The variable $C E B_{i}$ takes on the value of 1 for banks selected into the capital exercise, and 0 otherwise. CY Characteristic $c_{c}$ are

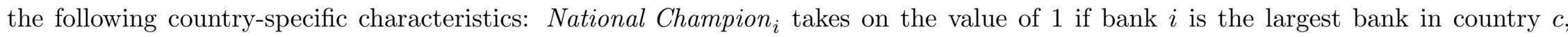
and 0 otherwise; Official Supervisory Power $_{c}$ comes from Barth, Caprio, and Levine (2013) and measures the degree to which national supervisors have the authority to take specific actions; Fiscal Constraints ${ }_{c}$ is the current account balance to GDP ratio; Credit Standards ${ }_{c}$

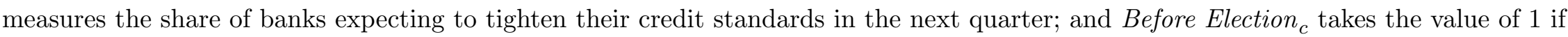
the capital exercise took place 12 months before the next national congressional election, and 0 otherwise. We control for the same bank characteristics as in the previous tables. $\gamma_{c}$ denote country fixed effects. Standard errors are clustered at the country level. *, **, and $* * *$ indicate statistical significance at the $10 \%, 5 \%$, and $1 \%$ levels, respectively.

$\Delta(\text { Regulatory Capital/Book Equity })_{2010-2012}$

CEB

CEB × CT1 Ratio 2010

National Champion

$-0.058$

(0.037)

CEB $\times$ Official Supervisory Power

$\mathrm{CEB} \times$ Fiscal Constraints

CEB $\times$ Credit Standards

CEB $\times$ Before Election

\section{Controls}

Country FE

$\mathrm{N}$

$R^{2}$

Yes
Yes
191
0.339

$\begin{array}{cc}0.111^{* *} & 0.093^{* *} \\ (0.050) & (0.039) \\ & \\ -0.058 & \\ (0.037) & \\ & 0.062^{* *} \\ & (0.024)\end{array}$

$-0.011$

$(0.007)$

$0.104^{* *}$
$(0.040)$

0.014

$(0.027)$

$0.109^{* *}$

(0.051)

$0.051^{*}$

(0.027)

$0.191^{* *}$

(0.078)

$0.015^{*}$

$(0.008)$

$-0.073^{* *}$

$-0.064^{* *}$

$(0.030)$

$(0.028)$

$0.040^{* * *} \quad 0.030^{* *}$

(0.009)

$(0.011)$

$-0.006^{* *}$

$-0.004$

$(0.003) \quad(0.003)$

$0.003^{* * *} \quad 0.003^{* *}$

$0.004^{* * *}$

(0.001)

(0.001)

(0.001)

$-0.057$

$-0.050$

(0.058)

(0.040)

$-0.043$

(0.037)
Yes

Yes

191

0.368

Yes
Yes
181
0.428

Yes

Yes

191
Yes
Yes
181

Yes

Yes

181

0.470 


\section{Table IX}

\section{Placebo Treatment Periods}

Table IX presents the estimation results of the change in the ratio of regulatory core tier 1 (CT1) capital to total equity around the 2011 EBA capital exercise and around two placebo treatment periods:

$$
Y_{i}=\alpha+\beta \times \mathrm{CEB}_{i}+\sum_{k} \theta^{k} X_{i}^{k}+\gamma_{c}+\epsilon_{i}
$$

where the dependent variable $Y_{i}$ is the change in the ratio of regulatory core tier 1 (CT1) capital to total book equity from 2010 to 2012 (treatment period), 2008 to 2010, and 2012 to 2014 (placebo periods), respectively. The variable $C E B_{i}$ takes on the value of 1 for banks selected into the capital exercise, and 0 otherwise. We control for the following bank characteristics $X_{i}^{k}$ as of 2010: $\log$ total assets, CT1 ratio, customer loans as a share of total assets, net interest income as a share of total operating revenue, depository funding as a share of total assets, and net income over total assets. $\gamma_{c}$ denote country fixed effects. Standard errors are clustered at the country level. *, **, and *** indicate statistical significance at the $10 \%, 5 \%$, and $1 \%$ levels, respectively.

\begin{tabular}{lccc}
\hline \hline & & & \\
& $\Delta_{2010-2012}$ & $\Delta_{2008-2010}$ & $\Delta_{2012-2014}$ \\
& Treatment & Placebo & Placebo \\
CEB & $0.100^{* *}$ & 0.003 & 0.002 \\
& $(0.045)$ & $(0.025)$ & $(0.023)$ \\
Bank-Level Controls & Yes & Yes & Yes \\
Country FE & Yes & Yes & Yes \\
N & & & 178 \\
$R^{2}$ & 191 & 0.28 & 0.25 \\
& 0.33 & & \\
\hline \hline
\end{tabular}


Table X

Matching Results

Table $\mathrm{X}$ presents the estimation results of the change in the ratio of regulatory capital to book equity using the matching strategies based on Gropp, Mosk, Ongena, and Wix (2019) described in Section IV. In each column, the first row contains the difference in the outcome variable for capital exercise banks (CEB) between the period before (2010) and the after (2012) the capital exercise; the second row contains the difference in the outcome variable for matched control group (control) banks over the same period. The paper tests for differences-in-means using Welch's two-sample t-test. The third row contains the estimate for the average treatment effect on the treated (ATT) based on the bias-corrected Abadie and Imbens (2011) matching estimator. Column 1 presents the results for the full sample matching strategy, Column 2 the results for the overlap matching strategy, Column 3 the results for the within-country matching strategy, and Column 4 the results for the within-region matching strategy. ${ }^{*},{ }^{* *}$, and *** indicate statistical significance at the $10 \%$, $5 \%$, and $1 \%$ levels, respectively.

\begin{tabular}{lcccc}
\hline \hline & \multicolumn{4}{c}{$\Delta(\text { Regulatory Capital/Book Equity })_{2010-2012}$} \\
\cline { 2 - 5 } & Full & Overlap & Within Country & Within Region \\
& & & & $0.09^{* *}$ \\
CEB: After - Before & $0.09^{* * *}$ & $0.09^{* * *}$ & $0.09^{* *}$ & -0.02 \\
Control: After - Before & 0.01 & 0.00 & -0.01 & $0.09^{* *}$ \\
Bias-Corrected ATT & $0.08^{* *}$ & 0.09 & $0.10^{* * *}$ & 26 \\
Number of Observations & 48 & 48 & 25 & \\
& & & & \\
\hline \hline
\end{tabular}


Online appendix for:

"Supranational rules, national discretion:

Increasing versus inflating regulatory bank capital?" 


\title{
Online Appendix 1: Book Equity, Capital Deductions, and Regulatory Capital
}

This table illustrates the calculation of regulatory common equity tier 1 (CET1) capital via the application of capital deductions to book equity (Common Equity Tier 1 capital before regulatory deductions) according to the social Basel disclosure template (BCBS, 2011).

\author{
Item \\ Common share capital plus related stock surplus \\ $+\quad$ Retained earnings \\ $+\quad$ Accumulated other comprehensive income (AOCI) \\ $+\quad$ Directly issued capital subject to phase out from CET1 \\ $+\quad$ Common share capital issued by subsidiaries and held by third parties \\ $=\quad$ Common Equity Tier 1 capital before regulatory deductions (Book Equity) \\ - $\quad$ Prudential valuation deductions \\ - $\quad$ Goodwill (net of related tax liability) \\ - $\quad$ Intangibles other than mortgage-servicing rights (net of related tax liability) \\ - $\quad$ Deferred tax assets \\ - $\quad$ Cash-flow hedge reserve \\ - $\quad$ Shortfall of provisions to expected losses \\ - $\quad$ Securitisation gain on sale \\ - $\quad$ Gains and losses due to changes in own credit risk on fair valued liabilities \\ - $\quad$ Defined-benefit pension fund net assets \\ - $\quad$ Investments in own shares \\ - $\quad$ Reciprocal cross-holdings in common equity \\ - $\quad$ Investments in the capital of financial institutions [. . . ] (above 10\% threshold) \\ - $\quad$ Significant investments in financial institutions [. . . ] (above 10\% threshold) \\ - $\quad$ Mortgage servicing rights \\ - $\quad$ Deferred tax assets arising from temporary differences \\ - $\quad$ Amount exceeding the $15 \%$ threshold \\ of which: Significant investments in the common stock of financials \\ of which: mortgage servicing rights \\ of which: deferred tax assets arising from temporary differences \\ - National specific regulatory deductions \\ - $\quad$ Deductions applied to CET1 due to insufficient AT1 and T2 \\ = Common Equity Tier 1 capital (CET1) (Regulatory Capital)
}




\section{Online Appendix 2: Anecdotic evidence of forbearance by national authorities}

We hand collected from annual reports, pillar 3 reports and EC state aid cases anecdotic evidence of forbearance by national authorities. Below we discuss three different methods how national authorities could forbear their banks.

\section{Recapitalizations}

One group of forbearance measures are ad hoc recapitalizations, such as the issuance of core tier 1 eligible hybrid securities, underwritten by the state. Germany (NORD/LB), Italy (Banca Monte dei Paschi di Siena), Portugal (Banco BPI, Banco Comercial Portugues, Caixa Geral de Depositos) and Slovenia (NLB, Nova Kreditna Banka Maribor) provided these instruments and often explicitly referred to the EBA capital as an important reason to justify the state aid measure. For example, the state aid application of Banco Comercial Português notes "On 8 December 2011,the EBA published a Recommendation related to banks' recapitalisation needs. ... In the light of the foregoing, the BCP Group needed to raise substantial additional capital by 30 June 2012. ". ${ }^{1}$ Capital assistance measures need a legal basis and thus approval from the parliament. The legal basis of the assistance to Banco Comercial Português is Law No $4 / 2012$ which has been enacted on January $11^{\text {th }}, 2012 .^{2}$ Besides direct capital support measures, several countries implemented around the EBA capital exercise regulation aiming to increase the regulatory capital of banks. We discuss several of these measures below.

\section{Conversion of deferred tax assets into tax credits}

Deferred tax assets are items on the bank's balance sheet that may be used to reduce taxable income in the future. Capital Requirements Regulation No. 575/2013 requires banks to deduct deferred tax assets from core tier 1 capital, because their dependence on future income, which depresses bank capital. The Italian government, however, enacted decree-law no. 201 on 6 December $2011^{3}$, allowing banks to convert their deferred tax assets into tax credits, which do not have to be deducted because they are guaranteed by the government. Similar regulatory changes have been implemented in the subsequent years by Spain, Portugal and Greece, resulting in a European Commission investigation whether these measures constitute illegal state aid.

\footnotetext{
1 State aid case SA.34724. https://ec.europa.eu/competition/elojade/isef/case_details.cfm?proc_code=3_SA_34724

${ }^{2}$ https://dre.pt/application/conteudo/477151

${ }^{3}$ https://www.normattiva.it/uri-res/N2Ls?urn:nir:stato:decreto.legge:2011;98
} 


\section{Deductions of tax treatment of goodwill impairments}

For prudential purposes, the book value of intangible assets and goodwill is deducted from CT1 capital because they may become worthless when banks go bankrupt. However, these assets are typically large in magnitude relative to a bank's regulatory capital $(24 \%$ for capital exercise banks in our sample as of 2010). Banks could reduce intangible asset deductions by impairing these assets. From an accounting perspective, this results in a decrease of the book value of goodwill (equal to the amount of the impairment charge) but also reduces net income (by that same amount). The impact on CT1 capital is initially capital neutral because, on the one hand, the impairment charge reduces CT1-deductions but, on the other hand, it also reduces profits which is a component of CT1 capital. One way national authorities could support banks is to allow tax-deductible intangible asset impairments, resulting in a net increase in regulatory capital after an impairment. ${ }^{4}$ In 2011, the Italian government enacted Law Decree no. 98/2011 ${ }^{5}$, allowing banks to boost their regulatory capital by impairing intangible assets. For example, the measure resulted in a 40 basis points increase in the regulatory capital of Banca Monte dei Paschi di Siena's. ${ }^{6}$

\footnotetext{
${ }^{4}$ Assume a bank impairs goodwill for an amount of 1,000 EUR which is tax-deductible. The tax rate is $20 \%$. This will result in a reduction of 1,000 EUR in capital deductions (thus increasing CT1 capital) whereas net income will decrease with 800 EUR $(1,000 *(1-0,2))$ rendering an net positive effect on CT1 capital of 200 EUR due to a permanent difference between book and tax income.

${ }^{5}$ https://www.normattiva.it/uri-res/N2Ls?urn:nir:stato:decreto.legge:2011-07-06;98!vig=

6 https:/www.gruppomps.it/en/media-and-news/press-releases/banca-monte-dei-paschi-siena-tier-1-up-to-8-8per-cent.html
} 


\section{Online Appendix 3: Pre-Treatment Characteristics of Banks}

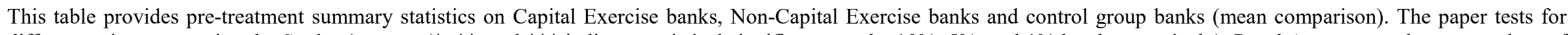
differences in means using the Student's t-test. (*, **, and *** indicate statistical significance at the $10 \%, 5 \%$, and $1 \%$ level respectively). Panel A compares the mean values of the 48 Capital Exercise banks and 145 Non-Capital Exercise banks in the unmatched sample. Panel B compares the 48 Capital Exercise banks to the full sample of matched control group banks based on the Mahalanobis matching estimator. Panels $\mathrm{C}$ to E compare Capital Exercise banks to the sample of matched control group banks using the overlap, within country and within region matching strategy respectively. Table I lists the matching covariates for each matching strategy.

\begin{tabular}{|c|c|c|c|c|c|c|c|c|c|c|c|c|}
\hline & \# Banks & $\begin{array}{l}\text { Total } \\
\text { Assets }\end{array}$ & & $\begin{array}{l}\text { Core } \\
\text { Tier } 1 \\
\text { Ratio } \\
\end{array}$ & & $\begin{array}{l}\text { Total } \\
\text { Deposits / } \\
\text { Total Assets }\end{array}$ & & $\begin{array}{l}\text { Customer } \\
\text { Loans / } \\
\text { Total Assets }\end{array}$ & & $\begin{array}{l}\text { Net Interest Income / } \\
\text { Operating Revenue }\end{array}$ & & $\begin{array}{l}\text { Net Income / } \\
\text { Total Assets }\end{array}$ \\
\hline \multicolumn{13}{|l|}{ Panel A: Unmatched Sample } \\
\hline Capital Exercise Banks & 48 & 454.31 & & 9.86 & & 40.93 & & 56.73 & & 60.42 & & 0.39 \\
\hline Non-Capital Exercise Banks & 144 & 24.43 & & 11.41 & & 55.54 & & 66.62 & & 67.69 & & 0.41 \\
\hline$\Delta$ & & 429.87 & $* * *$ & -1.55 & $* *$ & -14.61 & $* * *$ & -9.89 & $* * *$ & -7.27 & $* *$ & -0.02 \\
\hline \multicolumn{13}{|l|}{ Panel B: Full Sample } \\
\hline Capital Exercise Banks & 48 & 454.31 & & 9.86 & & 40.93 & & 56.73 & & 60.42 & & 0.39 \\
\hline Matched Control Group & 48 & 107.14 & & 10.30 & & 47.89 & & 64.80 & & 64.62 & & 0.41 \\
\hline$\Delta$ & & 347.17 & $* * *$ & -0.44 & & -6.95 & $* * *$ & -8.07 & $* * *$ & -4.19 & $* * *$ & -0.02 \\
\hline \multicolumn{13}{|l|}{ Panel C: Overlap Sample } \\
\hline Capital Exercise Banks & 36 & 161.32 & & 9.98 & & 41.97 & & 59.78 & & 61.95 & & 0.40 \\
\hline Matched Control Group & 36 & 156.10 & & 10.95 & & 53.80 & & 57.06 & & 71.89 & & 0.38 \\
\hline$\Delta$ & & 5.22 & & -0.96 & & -11.83 & $* *$ & 2.72 & & -9.94 & & 0.02 \\
\hline \multicolumn{13}{|l|}{ Panel D: Within Country } \\
\hline Capital Exercise Banks & 25 & 320.88 & & 9.96 & & 43.51 & & 59.08 & & 58.80 & & 0.40 \\
\hline Matched Control Group & 25 & 80.92 & & 10.80 & & 43.21 & & 61.72 & & 71.22 & & 0.42 \\
\hline$\Delta$ & & 239.96 & $* * *$ & -0.84 & $*$ & 0.31 & & -2.64 & & -12.42 & $*$ & -0.02 \\
\hline \multicolumn{13}{|l|}{ Panel E: Within Region } \\
\hline Capital Exercise Banks & 26 & 310.18 & & 10.01 & & 44.85 & & 59.77 & & 58.99 & & 0.45 \\
\hline Matched Control Group & 26 & 108.31 & & 9.73 & & 48.26 & & 65.69 & & 61.31 & & 0.45 \\
\hline$\Delta$ & & 201.87 & $* *$ & 0.28 & & -3.41 & & -5.92 & $* * *$ & -2.31 & & 0.00 \\
\hline
\end{tabular}


Online Appendix 4: Robustness of the results after excluding individual countries and banks

Online Appendix 4 replicates the results of Table 3 column (3) and (4) and subsequently estimates equation (1) for subsamples excluding one specific country (Panel A) or CE bank (Panel B).

Panel A: Robustness of the results after excluding individual countries

\begin{tabular}{|c|c|c|c|c|c|c|c|c|c|c|c|}
\hline & CEB & Controls & CY FE & Obs. & R-sq & CEB & CEB x CT1 Ratio 2010 & Controls & CY FE & Obs. & R-sq \\
\hline All CY's & $0.100 * *$ & YES & YES & 191 & 0.326 & $0.394 * * *$ & $-0.032 * * *$ & YES & YES & 191 & 0.401 \\
\hline \multicolumn{12}{|l|}{ Excluding: } \\
\hline Austria & $0.103 * *$ & YES & YES & 184 & 0.335 & $0.401 * * *$ & $-0.032 * * *$ & YES & YES & 184 & 0.413 \\
\hline Belgium & $0.098 * *$ & YES & YES & 189 & 0.326 & $0.393 * * *$ & $-0.032 * * *$ & YES & YES & 189 & 0.401 \\
\hline Cyprus & $0.100 * *$ & YES & YES & 190 & 0.316 & $0.394 * * *$ & $-0.032 * * *$ & YES & YES & 190 & 0.392 \\
\hline Denmark & $0.106^{* *}$ & YES & YES & 167 & 0.339 & $0.437 * * *$ & $-0.037 * * *$ & YES & YES & 167 & 0.418 \\
\hline Finland & $0.102 * *$ & YES & YES & 188 & 0.330 & $0.394 * * *$ & $-0.032 * * *$ & YES & YES & 188 & 0.403 \\
\hline France & $0.098^{*}$ & YES & YES & 185 & 0.322 & $0.396^{* * *}$ & $-0.032 * * *$ & YES & YES & 185 & 0.398 \\
\hline Germany & $0.098^{*}$ & YES & YES & 151 & 0.361 & $0.416^{* * *}$ & $-0.034 * * *$ & YES & YES & 151 & 0.436 \\
\hline Greece & $0.100 * *$ & YES & YES & 191 & 0.326 & $0.394 * * *$ & $-0.032 * * *$ & YES & YES & 191 & 0.401 \\
\hline Hungary & $0.100 * *$ & YES & YES & 190 & 0.326 & $0.394 * * *$ & $-0.032 * * *$ & YES & YES & 190 & 0.401 \\
\hline Ireland & $0.100 * *$ & YES & YES & 190 & 0.324 & $0.394 * * *$ & $-0.032 * * *$ & YES & YES & 190 & 0.399 \\
\hline Italy & 0.083 & YES & YES & 162 & 0.338 & $0.325 * *$ & $-0.025 * *$ & YES & YES & 162 & 0.388 \\
\hline Luxembourg & $0.104 * *$ & YES & YES & 189 & 0.328 & $0.395 * * *$ & $-0.032 * * *$ & YES & YES & 189 & 0.401 \\
\hline Malta & $0.101 * *$ & YES & YES & 189 & 0.327 & $0.394 * * *$ & $-0.032 * * *$ & YES & YES & 189 & 0.401 \\
\hline Netherlands & $0.108 * *$ & YES & YES & 186 & 0.336 & $0.415 * * *$ & $-0.033 * * *$ & YES & YES & 186 & 0.414 \\
\hline Norway & $0.108 * *$ & YES & YES & 167 & 0.329 & $0.402 * * *$ & $-0.032 * * *$ & YES & YES & 167 & 0.406 \\
\hline Poland & $0.106^{* *}$ & YES & YES & 188 & 0.336 & $0.394 * * *$ & $-0.031 * * *$ & YES & YES & 188 & 0.408 \\
\hline Portugal & $0.064 *$ & YES & YES & 185 & 0.264 & $0.321 * * *$ & $-0.027 * * *$ & YES & YES & 185 & 0.344 \\
\hline Slovenia & $0.101 * *$ & YES & YES & 188 & 0.326 & $0.415 * * *$ & $-0.034 * * *$ & YES & YES & 188 & 0.406 \\
\hline Spain & $0.112 * *$ & YES & YES & 181 & 0.337 & $0.408 * * *$ & $-0.032 * * *$ & YES & YES & 181 & 0.412 \\
\hline Sweden & $0.103 * *$ & YES & YES & 184 & 0.339 & $0.395 * * *$ & $-0.032 * * *$ & YES & YES & 184 & 0.403 \\
\hline United Kingdom & $0.097^{*}$ & YES & YES & 176 & 0.327 & $0.387^{* * *}$ & $-0.031 * * *$ & YES & YES & 176 & 0.401 \\
\hline
\end{tabular}


Panel B: Robustness of the results after excluding individual CE banks

\begin{tabular}{|c|c|c|c|c|c|c|c|c|c|c|c|c|}
\hline & Country & CEB & Controls & CY FE & Obs. & R-sq & CEB & CEB x CT1 Ratio 2010 & Controls & CY FE & Obs. & R-sq \\
\hline All banks & & $0.100 * *$ & YES & YES & 191 & 0.326 & $0.394 * * *$ & $-0.032 * * *$ & YES & YES & 191 & 0.401 \\
\hline \multicolumn{13}{|l|}{ Excluding: } \\
\hline BNP Paribas & France & $0.100 * *$ & YES & YES & 190 & 0.327 & $0.395 * * *$ & $-0.032 * * *$ & YES & YES & 190 & 0.401 \\
\hline Monte dei Paschi di Siena & Italy & $0.081^{*}$ & YES & YES & 190 & 0.325 & $0.319 * * *$ & $-0.025 * * *$ & YES & YES & 190 & 0.380 \\
\hline Banco BPI & Portugal & $0.086^{* *}$ & YES & YES & 190 & 0.283 & $0.393 * * *$ & $-0.033 * * *$ & YES & YES & 190 & 0.380 \\
\hline BBVA & Spain & $0.101 * *$ & YES & YES & 190 & 0.328 & $0.395 * * *$ & $-0.032 * * *$ & YES & YES & 190 & 0.402 \\
\hline Banco Comercial Portugues & Portugal & $0.092 * *$ & YES & YES & 190 & 0.282 & $0.344 * * *$ & $-0.027 * * *$ & YES & YES & 190 & 0.344 \\
\hline Banco Popolare & Italy & $0.099 * *$ & YES & YES & 190 & 0.320 & $0.416^{* * *}$ & $-0.034 * * *$ & YES & YES & 190 & 0.400 \\
\hline Banco Popular Espanol & Spain & $0.107 * *$ & YES & YES & 190 & 0.333 & $0.400 * * *$ & $-0.032 * * *$ & YES & YES & 190 & 0.407 \\
\hline Banco Santander & Spain & $0.100 * *$ & YES & YES & 190 & 0.326 & $0.397 * * *$ & $-0.032 * * *$ & YES & YES & 190 & 0.402 \\
\hline Bank of Valletta & Malta & $0.101 * *$ & YES & YES & 190 & 0.327 & $0.394 * * *$ & $-0.032 * * *$ & YES & YES & 190 & 0.401 \\
\hline Banque et Caisse d'Epargne & Luxembourg & $0.104 * *$ & YES & YES & 190 & 0.328 & $0.395 * * *$ & $-0.032 * * *$ & YES & YES & 190 & 0.401 \\
\hline Barclays & United Kingdom & $0.100 * *$ & YES & YES & 190 & 0.327 & $0.393 * * *$ & $-0.032 * * *$ & YES & YES & 190 & 0.401 \\
\hline Caixa Geral de Depositos & Portugal & $0.100 * *$ & YES & YES & 190 & 0.316 & $0.394 * * *$ & $-0.032 * * *$ & YES & YES & 190 & 0.392 \\
\hline Credit Agricole Group & France & $0.100 * *$ & YES & YES & 190 & 0.325 & $0.395 * * *$ & $-0.032 * * *$ & YES & YES & 190 & 0.401 \\
\hline DNB Bank & Norway & $0.100 * *$ & YES & YES & 190 & 0.327 & $0.396 * * *$ & $-0.032 * * *$ & YES & YES & 190 & 0.402 \\
\hline Danske Bank & Denmark & $0.099 * *$ & YES & YES & 190 & 0.326 & $0.394 * * *$ & $-0.032 * * *$ & YES & YES & 190 & 0.401 \\
\hline DekaBank & Germany & $0.100 * *$ & YES & YES & 190 & 0.324 & $0.397 * * *$ & $-0.032 * * *$ & YES & YES & 190 & 0.400 \\
\hline Deutsche Bank & Germany & $0.100 * *$ & YES & YES & 190 & 0.324 & $0.395 * * *$ & $-0.032 * * *$ & YES & YES & 190 & 0.399 \\
\hline DZ bank & Germany & $0.099 * *$ & YES & YES & 190 & 0.322 & $0.395 * * *$ & $-0.032 * * *$ & YES & YES & 190 & 0.397 \\
\hline Erste Group Bank & Austria & $0.099 * *$ & YES & YES & 190 & 0.326 & $0.394 * * *$ & $-0.032 * * *$ & YES & YES & 190 & 0.400 \\
\hline Espirito Santo & Portugal & $0.104 * *$ & YES & YES & 190 & 0.344 & $0.419 * * *$ & $-0.034 * * *$ & YES & YES & 190 & 0.428 \\
\hline La Caixa & Spain & $0.099 * *$ & YES & YES & 190 & 0.325 & $0.395 * * *$ & $-0.032 * * *$ & YES & YES & 190 & 0.400 \\
\hline Groupe BPCE & France & $0.099 * *$ & YES & YES & 190 & 0.324 & $0.394 * * *$ & $-0.032 * * *$ & YES & YES & 190 & 0.399 \\
\hline
\end{tabular}


Panel B: Robustness of the results after excluding individual CE banks (Continued)

\begin{tabular}{|c|c|c|c|c|c|c|c|c|c|c|c|c|}
\hline & Country & CEB & Controls & CY FE & Obs. & R-sq & CEB & CEB x CT1 Ratio 2010 & Controls & CY FE & Obs. & R-sq \\
\hline HSBC & United Kingdom & $0.100 * *$ & YES & YES & 190 & 0.327 & $0.394 * * *$ & $-0.032 * * *$ & YES & YES & 190 & 0.401 \\
\hline Intesa Sanpaolo & Italy & $0.098 * *$ & YES & YES & 190 & 0.319 & $0.393 * * *$ & $-0.032 * * *$ & YES & YES & 190 & 0.393 \\
\hline Jyske Bank & Denmark & $0.101 * *$ & YES & YES & 190 & 0.327 & $0.399 * * *$ & $-0.032 * * *$ & YES & YES & 190 & 0.402 \\
\hline Landesbank Berlin & Germany & $0.099 * *$ & YES & YES & 190 & 0.324 & $0.398 * * *$ & $-0.032 * * *$ & YES & YES & 190 & 0.399 \\
\hline Landesbank Hessen-Thuringen & Germany & $0.103 * *$ & YES & YES & 190 & 0.332 & $0.413 * * *$ & $-0.033 * * *$ & YES & YES & 190 & 0.413 \\
\hline Lloyds Banking Group & United Kingdom & $0.101 * *$ & YES & YES & 190 & 0.328 & $0.394 * * *$ & $-0.032 * * *$ & YES & YES & 190 & 0.402 \\
\hline NORD/LB & Germany & $0.094 *$ & YES & YES & 190 & 0.320 & $0.382 * * *$ & $-0.031 * * *$ & YES & YES & 190 & 0.382 \\
\hline Nordea Bank & Sweden & $0.099 * *$ & YES & YES & 190 & 0.326 & $0.397 * * *$ & $-0.032 * * *$ & YES & YES & 190 & 0.402 \\
\hline Nova Kreditna banka Maribor & Slovenia & $0.099 * *$ & YES & YES & 190 & 0.326 & $0.394 * * *$ & $-0.032 * * *$ & YES & YES & 190 & 0.400 \\
\hline Nova Ljubljanska Banka & Slovenia & $0.100 * *$ & YES & YES & 190 & 0.327 & $0.407 * * *$ & $-0.033 * * *$ & YES & YES & 190 & 0.405 \\
\hline Nykredit Realkredit & Denmark & $0.101 * *$ & YES & YES & 190 & 0.329 & $0.420 * * *$ & $-0.035 * * *$ & YES & YES & 190 & 0.405 \\
\hline OP Financial Group & Finland & $0.103 * *$ & YES & YES & 190 & 0.328 & $0.393 * * *$ & $-0.032 * * *$ & YES & YES & 190 & 0.400 \\
\hline OTP Bank Nyrt. & Hungary & $0.100 * *$ & YES & YES & 190 & 0.326 & $0.394 * * *$ & $-0.032 * * *$ & YES & YES & 190 & 0.401 \\
\hline Permanent TSB Group & Ireland & $0.100 * *$ & YES & YES & 190 & 0.324 & $0.394 * * *$ & $-0.032 * * *$ & YES & YES & 190 & 0.399 \\
\hline Powszechna Bank & Poland & $0.106^{* *}$ & YES & YES & 190 & 0.333 & $0.393 * * *$ & $-0.031 * * *$ & YES & YES & 190 & 0.405 \\
\hline Rabobank Group & Netherlands & $0.100 * *$ & YES & YES & 190 & 0.327 & $0.400 * * *$ & $-0.032 * * *$ & YES & YES & 190 & 0.402 \\
\hline Raiffeisen Bank & Austria & $0.102 * *$ & YES & YES & 190 & 0.328 & $0.400 * * *$ & $-0.032 * * *$ & YES & YES & 190 & 0.404 \\
\hline SNS Bank & Netherlands & $0.104 * *$ & YES & YES & 190 & 0.329 & $0.412 * * *$ & $-0.033 * * *$ & YES & YES & 190 & 0.408 \\
\hline Skandinaviska Enskilda Banken & Sweden & $0.100 * *$ & YES & YES & 190 & 0.328 & $0.391 * * *$ & $-0.031 * * *$ & YES & YES & 190 & 0.401 \\
\hline Societe Generale & France & $0.099 * *$ & YES & YES & 190 & 0.324 & $0.394 * * *$ & $-0.032 * * *$ & YES & YES & 190 & 0.399 \\
\hline Svenska Handelsbanken & Sweden & $0.100 * *$ & YES & YES & 190 & 0.326 & $0.403 * * *$ & $-0.033 * * *$ & YES & YES & 190 & 0.403 \\
\hline Swedbank & Sweden & $0.101 * *$ & YES & YES & 190 & 0.328 & $0.396^{* * *}$ & $-0.032 * * *$ & YES & YES & 190 & 0.400 \\
\hline Sydbank & Denmark & $0.102 * *$ & YES & YES & 190 & 0.328 & $0.397 * * *$ & $-0.032 * * *$ & YES & YES & 190 & 0.401 \\
\hline UniCredit & Italy & $0.099 * *$ & YES & YES & 190 & 0.322 & $0.395 * * *$ & $-0.032 * * *$ & YES & YES & 190 & 0.397 \\
\hline UBI & Italy & $0.097 * *$ & YES & YES & 190 & 0.318 & $0.397 * * *$ & $-0.032 * * *$ & YES & YES & 190 & 0.393 \\
\hline WGZ bank & Germany & $0.101 * *$ & YES & YES & 190 & 0.326 & $0.395 * * *$ & $-0.032 * * *$ & YES & YES & 190 & 0.400 \\
\hline
\end{tabular}




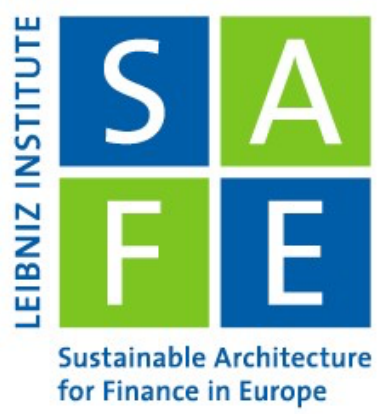

\section{Recent Issues}

No. 295 Besart Avdiu, Alfons J. Weichenrieder

No. 294 Christian Alemán, Christopher Busch, Alexander Ludwig, Raül Santaeulàlia-Llopis

No. 293 Christoph Hambel, Holger Kraft, André Meyer-Wehmann

No. 292 Andrea Modena

No. 291 Loriana Pelizzon, Satchit Sagade, Katia Vozian

No. 290 Nicola Fuchs-Schündeln, Dirk Krueger, Alexander Ludwig, Irina Popova

No. 289 Christian Schlag, Michael Semenischev, Julian Thimme

No. 288 Michele Costola, Michael Nofer, Oliver Hinz, Loriana Pelizzon

No. 287 Kevin Bauer, Nicolas Pfeuffer, Benjamin M. Abdel-Karim, Oliver Hinz, Michael Kosfeld

No. 286 Andreass Hackethal, Michael Kirchler, Christine Laudenbach, Michael Razen, Annika Weber

No. 285 Elena Carletti, Tommaso Oliviero, Marco Pagano, Loriana Pelizzon, Marti G. Subrahmanyam

No. 284 Monica Billio, Michele Costola, Iva Hristova, Carmelo Latino, Loriana Pelizzon

No. 283 Jannis Bischof, Christian Laux, Christian Leuz
Financing Costs and the Efficiency of PublicPrivate Partnerships

Evaluating the Effectiveness of Policies Against a Pandemic

When Should Retirees Tap Their Home Equity?

Recapitalization, Bailout, and Long-run Welfare in a Dynamic Model of Banking

Resiliency: Cross-Venue Dynamics with Hawkes Processes

The Long-Term Distributional and Welfare Effects of Covid-19 School Closures

Predictability and the Cross-Section of Expected Returns: A Challenge for Asset Pricing Models

Machine Learning Sentiment Analysis, COVID-19 News and Stock Market Reactions

The Terminator of Social Welfare? The Economic Consequences of Algorithmic Discrimination

On the (Ir)Relevance of Monetary Incentives in Risk Preference Elicitation Experiments

The COVID-19 Shock and Equity Shortfall: Firm-Level Evidence from Italy

Inside the ESG Ratings: (Dis)agreement and Performance

Accounting for Financial Stability: Bank Disclosure and Loss Recognition in the Financial Crisis 